2011

\title{
A Perspective from Honduras' Civil Society Truth Commission
}

Craig Scott

Osgoode Hall Law School of York University

Follow this and additional works at: http://digitalcommons.osgoode.yorku.ca/all_papers

\section{Repository Citation}

Scott, Craig, "A Perspective from Honduras' Civil Society Truth Commission" (2011). All Papers. Paper 24.

http://digitalcommons.osgoode.yorku.ca/all_papers/24

This Conference Paper is brought to you for free and open access by the Research Papers, Working Papers, Conference Papers at Osgoode Digital

Commons. It has been accepted for inclusion in All Papers by an authorized administrator of Osgoode Digital Commons. 


\section{A PERSPECTIVE FROM HONDURAS' CIVIL SOCIETY TRUTH COMMISSION: Speaking notes for a presentation to the March 9, 2011, Hearing on Honduras Convened by the Standing Committee on Foreign Affairs, House of Commons, Canada}

\section{Craig Scott}

\section{Table of Contents}

Introduction

1 - The civil-society Truth Commission (Comisión de Verdad, or CV)

2 - The Human Rights Situation

3 - Complementarity of the civil society CV and the official CVR

4 - The Future of the Rule of Law in and for Honduras

5 - Final Remarks

Appendix 1: List of Commissioners on the Comisión de Verdad

Appendix 2: List of Objectives in the Mandate of the Comisión de Verdad

Appendix 3: Two Emblematic Urgent-Action Cases from March 7, 2011
$2-4$

$4-6$

$6-8$

$8-10$

$11-12$

12

13

14

$15-17$

Appendix 4: Document tabled by Craig Scott in advance of the Standing

Committee Hearing: Reina Rivera Joya, Impunity in

Honduras (Post Coup d'Etat June 28, 2009): General Guidelines for Engagement

(October 2010, HIVOS/ Humanist Institute for Development Cooperation) 18 - 46

Appendix 5: Document tabled by Bertha Oliva in advance of the Standing Committee Hearing: COFADEH, Report on the Human Right Situation in Honduras (January 2010 to January 2011) (COFADEH, March 2011)

\footnotetext{
The present document consists of the speaking notes used as a basis for a brief presentation to the Standing Committee on Foreign Affairs and International Development of the House of Commons of Canada during a March 9, 2011, hearing on the situation in Honduras. The hearing was convened at the request of the Canadian Council for International Cooperation, which is a member of the 40-member Americas Policy Group of Canadian NGOs. Nothing has been edited in the text of this document. The following additions have been made: (a) the above table of contents, (b) three unnumbered footnotes (the present footnote as well as two later footnotes referring the reader to Appendix 4 and Appendix 5) and (b) two new appendices in addition to the three appendices that are part of the original document (see Appendices 1, 2 and 3). New Appendix 4 is the document Professor Scott circulated in advance to the Standing Committee, being a 10-page distillation of a 60-page report by HIVOS mentioned on the next page; the appendix includes the original Spanish document as well as the Parliamentary translation into English. New Appendix 5 is the document circulated to the Standing Committee in advance by another hearing witness, Bertha Oliva of COFADEH (Comité de Familiares de Detenidos-Desaparecidos de Honduras); this document is a distillation of the first chapter in COFADEH's March 2011 report on the human rights situation in Honduras between January 2010 and January 2011; it also is reproduced in the original Spanish and in English translation.
} 
Good afternoon, honourable Members of Parliament. My name is Craig Scott and I am a Professor of Law at Osgoode Hall Law School and also Director of the Nathanson Centre on Transnational Human Rights, Crime and Security of York University in Toronto. I am also one of nine commissioners on the non-governmental Comisión de Verdad (CV), or Truth Commission, established by the civil-society Plataforma de Derechos Humanos and inaugurated eight months ago in Honduras on June 28, 2010, which was the first anniversary of the 2009 coup d'état in that country. (See Appendix 1 for the list of commissioners and a brief note on their qualifications, at page 12.) I should indicate before proceeding further that I speak in my own capacity as a Commissioner, but nothing I say should be taken as speaking for the Commission as such although it is equally important to note that I believe my main messages are shared by my colleagues on the Commission.

You will be aware that the 2009 coup resulted in the activation of the 2001 treaty known as the Inter-American Democratic Charter, a treaty in which Canada was heavily involved in bringing into being. This activation led within a week of the coup to Honduras's suspension from the right to participate in the OAS. The United Nations General Assembly also acted swiftly as well by adopting by consensus - that is, without opposition from any member of the $\mathrm{UN}$ - a strongly worded condemnatory resolution, the first two paragraphs of which read as follows:

1. Condemns the coup d'état in the Republic of Honduras that has interrupted the democratic and constitutional order and the legitimate exercise of power in Honduras, and resulted in the removal of the democratically elected President of that country, Mr. José Manuel Zelaya Rosales;

2. Demands the immediate and unconditional restoration of the legitimate and Constitutional Government of the President of the Republic of Honduras, Mr. José Manuel Zelaya Rosales, and of the legally constituted authority in Honduras, so that he may fulfil the mandate for which he was democratically elected by the Honduran people;

Please note that I have earlier asked to have circulated to the Standing Committee a 10-page translation into English and French of extracts that I selected from a 60-page report recently 
prepared for the Dutch development NGO called HIVOS. Its title is Impunity in Honduras After the Coup d'État of June 28, 2009: Guidelines for Approacbing the Subject. I circulate it with HIVOS' permission. The analysis in that paper can be viewed as providing some of the working hypotheses that our Commission is investigating. ${ }^{1}$

I have four main purposes in the remaining minutes:

1) Explain briefly how the civil society Truth Commission, or CV, on which I have the privilege to sit with commissioners of far higher stature than myself, came to be, our mandate, what our method of work is, and our projected schedule to report.

2) Say something about the seriousness of the current human rights situation.

3) Comment on what I consider to be the complementarity of roles of the our civil-society Truth Commission and the official, governmental Truth and Reconciliation Commission (Comisión de la Verdad y de Reconciliación or CVR) appointed by the current holder of the Presidency, Pepe Lobo, who assumed office in January 2010. It is worth stating my key point now: this complementarity suggests strongly that there is great value if Hondurans, the OAS, Canada and Canadians, and other states have the benefit of the reports of both commissions in order to allow more informed, more inclusive, and more productive national and international deliberations on ways forward for Honduras.

4) Note some key questions that both Commissions will need to analyse from the perspective of the rule of law.

\footnotetext{
See Appendix 4 for this 10-page extract, in three languages.

${ }^{1} \mathrm{I}$ also take the liberty to mention an article that is in press and that will be published in two weeks in a journal of the Asian Human Rights Commission called ETHICS IN ACTION. The paper is called "The Transnationalization of Truth: A Meditation on Sri Lanka and Honduras" and will appear online at www.ethicsinaction.asia as well as in its print version. A working paper can be found at http://ssrn.com/abstract=1759072, but note that the final ETHICS IN ACTION paper has a number of additions to the Honduras section.
} 
I will not speak to every point in the present I have in front of me and that I have circulated to you, due to time limitations for the presentation, and will thus leave parts of the text to speak for themselves.

\section{1-The civil-society Truth Commission (Comisión de Verdad, or CV)}

After the coup, diplomatic negotiations and international pressures led to in fall 2009 to two accords, which set out a range of required courses of action for various actors to implement. It is too long a story to outline here but the majority of these courses of action were not implemented. But one course of action was followed though with after Porfirio (Pepe) Lobo assumed office as the holder of the Presidency. By executive decree, he established the just-mentioned Truth and Reconciliation Commission (Comisión de la Verdad y de Reconciliación, or CVR), which began its work in May 2010.2 Its mandate is to "clarify the facts that occurred before and after June 28, 2009, in order to identify the acts that led to the crisis situation and to make proposals to the Honduran people in order to avoid the repeat of such acts in the future." It was to have reported in approximately eight months, thus by around January 2011, but its Chair confirmed three days ago that mid-May is now the likely date. As you will likely know, the official CVR is constituted by five members, three foreigners and two Hondurans. They include a former Canadian Ambassador to the US, Michael Kergin, and, as Chair, Eduardo Stein, a former vice-president of Guatemala.

It is fair to say that deep mutual distrust within a polarized society is a defining feature of Honduras at present. Thus, it is perhaps unsurprising that the Plataforma de Derechos Humanos - of which Bertha Oliva's organization, COFADEH, is one of six members - decided to constitute its own commission. The overarching orientation within the mandate constituting the this civil-society Truth Commission is summed by the sentence that appears in it: "Sin verdad ni justicia no será posible la reconciliación de la familia hondureña." Without either truth or justice, reconciliation of the Honduran family will not be possible). More briefly, the Commission's motto within its communications to the public is Sin verdad no bay justicia (No justice without truth).

Generally put, the civil-society Commission has the mandate to investigate, document and analyze the nature and dimensions of that coup as well as the climate of human rights violations following

\footnotetext{
${ }^{2}$ The CVR's website is http://www.cvr.hn.
} 
the coup until the present. Necessary for coming to grips with these two fields of focus - the coup and the human rights situation in Honduras - is an understanding of the multiple dimensions of the fragile and compromised state of the rule of law in Honduras. A crucial part of our report will be recommendations on accountability of state and individual actors, on necessary structural and institutional reforms, and on desirable action from international institutions. As Appendix 2 (page 13) to these speaking notes, I have added my rough translation into English of the eight objectives within the Commission's mandate, which can be found in Spanish on the Commission's website at www.comisiondeverdadhonduras.org. The Commissioners will be assessing and starting revisions on the first complete draft of our report at the end of June, which will lead to a series of refinements and any necessary further research and analysis throughout the summer - leading finally, we expect, to release of the report in October in Spanish and in English.

The civil-society Commission is headed by an Executive Secretary, Mr. Tom Loudon of the United States; the Commissioners felt it was important that the Executive Secretary not be a Honduran for the sake of that person's security. It has, as you can imagine, been a challenge to begin a civilsociety Commission with no access to state funding from a standing start. The official CVR started with a budget of 3.5 to 4 million dollars, some of which has been provided by Canada. This is in contrast to our budget for which, to fully deliver on our workplan, we need to generate enough funds for something over $\$ 700,000$. Raising of funds of that amount is of course not easy. The Commissioners are all doing their work pro bono, so that helps. And the solidarity of civil society organizations mostly from Europe and also from Canada and the US has been crucial to date. Recently, the first pledge from a government has been confirmed. Germany will provide significant project funding for one or more aspects of our work.

Based in a headquarters established in Tegucigalpa in early fall, a team of staff members works with a number of consultants and advisers on a research agenda that has essentially four prongs:

$1^{\text {st }}$ prong) a contextualized historical and sociological study of the political, economic and social processes, structures and actors within which the coup and the human rights situation need to be situated for full understanding; this study includes how such processes and structures interact with and produce features of the legal system; 
$2^{\text {nd }}$ prong) a study of the nature of the coup, of the actors involved in the coup and of how and why the coup came about, both in factual terms and in terms of the legal justifications that have been offered by a range of actors within the coalition of actors involved in the coup;

$3^{\text {rd }}$ prong) a study of the human rights situation in Honduras involving systematic collection and evaluation of data, analysis of the relevant legal frameworks for assessing whether human rights violations have occurred (both in terms of specific incidents and patterns), and an application of the relevant legal norms to the data (with a special onus on the Commission to understand how acts and omissions generate responsibility for individuals and not only for the state); and

$4^{\text {th }}$ prong) analysis of options for recommendations to be put forward with attention to learning from accumulated comparative and international experience with remedying systemic and deeprooted rule of law deficits, with individual accountability for human rights violations and with achieving justice for conflict-ridden societies .

The just-mentioned third prong of research - into human rights violations - includes a massive effort to assess and verify human rights data gathered by a variety of human rights organizations as part of their own mandates and also taking testimony from two categories of persons: persons alleging violations who have not had their account recorded yet by other organizations and persons who have already told their stories but where the information provided has gaps that need to be filled. Apart from its headquarters, the Commission has opened two other offices in both of Honduras' two major cities, San Pedro Sula and - yesterday, March 8 - in Tegucigalpa. In addition, fanning out across the country to take testimony in locales other than San Pedro and Tegucigalpa are teams of a half-dozen persons (each team including trained interviewers and psychologists as well as non-Honduran accompaniers to provide some security). A multitude of methods of public communication have let Hondurans know about these information-gathering efforts and how they can contact the Commission to arrange for their confidential testimony to be given, securely, to the Commission.

\section{2-The Human Rights Situation}

Since the coup, a wide range of credible and authoritative institutions have issued reports on what is viewed as a serious deterioration in the human rights situation in Honduras since the coup, 
including from the Inter-American Commission on Human Rights, the UNHCHR and the International Commission of Jurists (ICJ). It is very important to know that such reports have by no means focused only on the six months between the coup and the holding of elections in November 2009. For example, the IACHR sent a field mission last May 2010, four months after Porfirio Lobo was inaugurated as President, and issued a highly critical report; and an interim report from the ICJ just this past December focuses on the serious problems with the rule of the law and the organization of impunity in Honduras. Although specifics and extent still require much more work from our Commission, it is impossible not to conclude that the situation in Honduras is one of human rights peril since the time of the coup - and this taking into account that Honduras was not a human rights paradise before the coup. More surprisingly for external observers, since the immediate post-coup regime headed up by Roberto Michelletti ceded to that of Porfirio Lobo after the November 2009 elections, the situation may not be getting better and indeed may be getting worse in important respects. Some examples are as follows:

- ongoing and indeed escalating threats to and attacks on human rights defenders and journalists;

- adoption of a seriously abuse-prone Anti-Terrorism Law that adds to other elements of the legal system as a means to suppress the peaceful social movement that arose to resist the coup (known as La Resistencia in its social manifestation and the Frente Hondureña de Resistencia Popular in its increasingly institutionalized dimension);

- violent suppression of an agrarian justice movements in an area of the country known as the Bajo Aguan;

- the use of the brief window since the November 2009 elections to enact a range of 'economic reform' laws that fit within a model of economic 'liberalization' that facilitates more not less control of resources and economic power in the hands of the already very powerful Honduran economic elites as well as transnational companies;

\footnotetext{
${ }^{\circ}$ See Appendix 5 for a 10-page extract prepared by Bertha Oliva of COFADEH, Informe - Situación de Derechos Humanos en Honduras (Enero 2010 a Enero 2011) (COFADEH, marzo 2011); the original Spanish is accompanied by the official Parliamentary translation into French and English.
} 
- heightened vulnerability of, including assassinations within, some long victimized communities such as the transsexual community, with an added element of gay men who assume a leadership role in their community and in Resistencia; and

- the solidifying, if not the deepening, of the structures of impunity from accountability for human rights violations within the current judicial, investigation and prosecutorial system.

I attach as Appendix 3 (page 14) to this presentation two Urgent Action alerts that COFADEH (the organization of which today's witness Bertha Oliva is Director) released on March 7, 2011. These two cases - for Leo Valladares and Trinidad Sánchez -- are emblematic examples of frequent occurrences. In terms of ubiquity of this kind of conduct involving surveillance and various forms of threats, members of the Standing Committee should also know that for a concentrated period last November and December (2010), a range of such practices occurred in relation to staff of the Commission in Tegucigalpa. I have been in touch with Canada's Ambassador to Costa Rica with responsibility for Honduras (Cameron MacKay) and asked for Canada's support should an even more serious event occur or should the accumulation of surveillance and threats become debilitating. Ambassador MacKay - and the former Ambassador before him, Mr Neil Reeder -- has responded with concern and asked to be alerted immediately of a serious event in order that he may consider what representations Canada might be able to take - alone or with other countries -- to the appropriate persons within the Honduran state. The potential for support from Canada's diplomatic corps is certainly welcome.

\section{3-Complementarity of the civil society CV and the official CVR}

At the outset, I indicated I wanted to speak to the complementarity of the work of the two commissions, our civil society CV and the governmental CVR. To repeat what I said in the introduction, there is great value if Hondurans, the OAS, Canada and Canadians, and other states have the benefit of the reports of both commissions in order to allow broader, more informed, and more inclusive national and international deliberations on ways forward for Honduras.

I am inclined to think about the relationship between the official CVR and the civil society CV (which at the moment is an entirely virtual one as the commissions have not met) in terms of keeping each other honest. I do not mean 'honest' in the literal sense but in the more figurative 
sense, according to which the presence of another institution with complementary and to some extent overlapping mandates keeps each institution on its toes in the sense that a markedly superior performance from the other institution - for example, in the form of a more persuasive report will 'show up' one's own institution. The result will, I hope, be a fuller truth, including as may be produced by discussion and debate about any differences in findings, interpretations, recommendations or emphasis between the two reports. In the most simplified sense, as I have said more than once to the media in Canada or Honduras, "more truth is better than less." In a more complex sense, though, it is my expectation that it will not only be a matter of quantity (more truth) - although that will certainly be the case on the pure factual findings side of things - as a quality thing (deeper truth): the presence of the CVR and the CV means the quality of what each produces should be higher than if the other did not exist as its shadow.

Within this way of thinking, it is very important to be aware of the different mandates and different emphases of the two commissions. The official CVR has been asked to focus on a "crisis" associated with June 28, 2009 - a "crisis" that is not characterized as a coup in the mandate text and its investigations are to stop with the end of the de facto Presidency of Roberto Michelletti and not extend into the regime of the current holder of the Presidency, Porfirio Lobo (which began when Lobo was inaugurated in late January 2010). Also, the human rights situation in Honduras is not specified in the President's mandate as a focus of the official CVR, and the term "human rights" receives only an indirect mention in the mandate. For that reason, on several occasions, the CVR's chair, Mr Stein, has had to make public statements seeking to alleviate concerns that, because of the wording of the CVR mandate, the CVR is not going to look seriously at human rights violations since the coup. Stein has emphasized that human rights violations are part of the CVR's inquiry - albeit, to emphasize again, only up to the start of the Lobo Presidency and thus with no coverage of the period since February 2010 to present.

There is also the important reality of access of the two commissions to different actors and different sources of evidence. The official CVR has - at least, by its mandate it has - full access to all executive branch documentation (subject to an important condition: at the time of the report, it may not reveal state-sensitive information and is required to provide copies of corresponding documents to the OAS for safeguarding before those documents can be made public in 10 years). Although the CVR does not have legally mandated access to Congress, as the mandate is created by 
way of an executive decree, it is reasonable to assume that the CVR will be granted more access than our CV to members of Congress as well as members of the Supreme Court, members of the military, the Attorney General and so on.

In contrast, the civil-society CV has much more extensive and higher quality access to information on the human rights situation in the country, both because of documentation that human rights NGOs, including members of the Plataforma, are assisting us with and because we have adopted an approach to documenting the situation through individual witness testimony. I am not aware which members of the former Zelaya cabinet has spoken with the CVR, but the CV has been granted access to some witnesses that we very much doubt have also been willing to speak to the CVR.

Apart from the above reasons for thinking of more and better truth as a result of the efforts of the two commissions, we also cannot forget prudential and strategic concerns. Honduras is a highly polarized society with immense distrust, including distrust of many Hondurans of the official CVR and obvious distrust of other sectors of our civil society CV. There are thus political legitimacy consequences if the Honduran government (President and Congress) moves ahead based solely on a CVR report. As such, to move ahead of having both reports is not just to lose the benefit of more knowledge and a healthier basis for debate and deliberation: it is also to risk (indeed, practically invite) exacerbation versus amelioration of fractures in Honduras. This would hardly be a recipe for the reconciliation that appears in the CVR's mandate and its very title. Such prudential considerations also apply to external actors considering how to engage Honduras including whether to 'reward' President Lobo for what appear to be positive moves; such moves include establishing the CVR, calling for an anti-impunity institution modelled on one set by the UN and Guatemala, setting up a Human Rights Ministry, and sending signals to the development assistance world that poverty and social cohesion are some sort of priority of his government). The OAS, for example, is viewed by many in Honduras as having sided with justice and the rule of law, even if pressure was ineffective in carrying out the OAS' own calls for the Micheletti regime to stand down and allow Zelaya to return to the presidency. If the OAS were to now act in a way that is received as an abandonment of its support for democracy and human rights, on the basis only of the CVR report, that authority and respect will take a huge hit from many in the country. Canada also has to consider the context in which it takes initiatives, including the planned free trade agreement between Canada and Honduras. 


\section{4-The Future of the Rule of Law in and for Honduras}

Each commission has its work cut out for it with respect to understanding the multiple ways in which the compromised state of the rule of law in Honduras - about which the HIVOS paper gives a good, if still not full, overview - is central to the problems of Honduras and in which transformation of that situation is central to any meaningful way forward for Honduras. I have no time in these remarks to elaborate but allow me to note simply six areas that will certainly figure in our report and that I imagine will also be analyzed in the CVR's report:

1. the role and responsibility of the Supreme Court both with respect to the coup and with respect to de facto impunity from legal accountability that many actors enjoy in Honduras;

2. the role of an administrative court that played a key role in ruling on the legality of former President Zelaya's two efforts to consult Hondurans on the question of a Constituent Assembly, which rulings set the scene for the Attorney General to lay various criminal charges against former President Zelaya;

3. the role of actors within the legal system that are supposed to be independent of the three powers such as the Ministerio Publico (Public Ministry that is headed by the Fiscal General, who we would call the Attorney General) and the Human Rights Commissioner known as CONADEH;

4. the adequacy of the present 1982 Constitution from the perspective of the aspirations of a huge number of Hondurans (the circulated HIVOS report notes some 1.5 million signatures by persons of voting age on a petition in fall 2010 calling for a Constituent Assembly that would overhaul the current Constitution) and pitfalls in the Constitution that block both social change and some kinds of changes to the constitution itself;

5. the intertwining of law, political philosophy and social moblization as relevant perspectives on the question of whether and how a new Constituent Assembly should be part of the way forward for the country; and

6. the forms of international institutional involvement that are both needed and acceptable (when considered within a broader perspective of Hondurans as a people controlling their own destiny), including whether an experiment with a hybrid institution (partly international and partly national) in operation in Guatemala (known as the International Commission against Impunity in Guatemala; Spanish acronym, CICIG) can serve as one institutional 
reform to be layered onto other necessary changes within Honduras legal system; essentially this includes whether the creation of a CICIG-like entity can be responsibly supported without prior radical reform to and within key institutions in Honduras such as the Supreme Court, the Ministerio Público and CONADEH.

\section{5.- Final Remarks}

Many Hondurans and many informed external observers, including in the diplomatic corps, see the situation in Honduras as dire - or, indeed, as one leading diplomat expressed it to me, as at the point of social and state collapse. The reasons are multiple and interconnected. They include: a climate of serious human rights violations including of economic, social and cultural rights; a highly problematic rule of law situation; murderous crime including as a result of the infestation of narcotics traffickers moving southward from Mexico and Guatemala and as a result of 10s of 1000s of youths who are organized into gangs known as maras and who appear to live in a universe of utter despair for their futures; a history of militarization and paramilitary activity that is now resurgent; longstanding extensive involvement of the United States including of the military and intelligence services of the US; of many Hondurans' deep distrust and resentment of the current political, economic and legal order; and the country's polarization between, on the one hand, social movements grounded in aspirations for meaningful participation in government and for prioritization of social justice and, on the other hand, two political parties with a history of controlling politics as well as being controlled by and acting on behalf of powerful economic and military elites. Canadians and MPs have an intersocietal responsibility to take this context into full account in seeking to influence the policies of the Government of Canada as itself an influential political and economic actor in Honduras.

These are my remarks. I welcome any questions from members of the Standing Committee. 


\section{Appendix 1}

In terms of membership, the Comisión de Verdad is made up of nine commissioners, two Hondurans and seven foreigners. Individual profiles can be found, in Spanish, on the Comisión de Verdad website at the URLs below:

Sister Elsie Monje, Chair (Ecuador) http://www.comisiondeverdadhonduras.org/node/11 -Executive Director, Frente Ecuatoriano de Derechos Humanos (FEDHU); recent Chair of Ecuador's national Truth Commission on human rights violations of the 1980s; nominated by 1000 women in 2006 for the Nobel Peace Prize

Helen Umaña (Honduras) http://www.comisiondeverdadhonduras.org/node/10 -- national cultural figure, professor of literature, and Laureate of Honduras' National Prize for Literature

Father Fausto Milla (Honduras) http://www.comisiondeverdadhonduras.org/node/9 -- Catholic priest with parish in Santa Rosa de Copán; nationally renowned human rights defender in Honduras; refugee in Mexico from 1982-85 after being targeted for assassination

Nora Cortiñas (Argentina) http://www.comisiondeverdadhonduras.org/node/6 -- Social psychologist and Co-founder of the Mothers of the Plaza de Mayo Movement founded in 1977; lost her son to 'disappearance' during military rule in Argentina; Honourary Doctorate from the Université Libre de Bruxelles in 2000

Adolfo Perez Esquivel (Argentina) http://www.comisiondeverdadhonduras.org/node/39 -Nobel Peace Prize Laureate, 1980

Francisco Aguilar (Costa Rica) http://www.comisiondeverdadhonduras.org/node/9 -- recent Ambassador of Costa Rica to the Netherlands; Member and President (1995-97), of the UN Human Rights Committee

Mirna Perla (El Salvador) http://www.comisiondeverdadhonduras.org/node/12 - Justice of the Supreme Court of El Salvador; survivor of massacre in 1975 and lost her husband to assassination in 1987; General Coordinator and Vice President, CODEHUCA (Comisión para la Defensa de los Derechos Humanos en Centroamérica), 1988-1992

Luis Catlos Nieto (Spain) http://www.comisiondeverdadhonduras.org/node/7 -- Judge (elevated to Magistrate) with specialization in youth justice; leading member of Judges for Democracy (Juezes para la Democracia); multiple field missions for Federación Internacional de Derechos Humanos (FIDH)

Craig Scott (Canada) http://www.comisiondeverdadhonduras.org/node/8 -- Professor of Law, Osgoode Hall Law School, and Director, Nathanson Centre on Transnational Human Rights, Crime and Security, York University, Toronto 


\section{Appendix 2}

The Comisión de Verdad's mandate consists of eight objectives. The following is my rough and provisional translation from the Spanish document:

- $\quad$ The CV shall investigate and establish the human rights violations that were occasioned by the coup of June 28,2009, and those that have continued to be perpetrated until the end of the CV's mandate, identifying, where possible, the persons responsible.

- $\quad$ The CV shall investigate and establish patterns of aggression and of the persecution to which human rights defenders and social leaders who promote structural change have been subjected, identifying the persons responsible.

- The CV shall assess the consequences of impunity and of the structures of repression that continue to operate in the country since the 1980s, and identify the mechanisms of impunity for past crimes that have permitted previous human rights violators to revive their activities within the setting of the coup.

- $\quad$ The CV shall identify the antecedents of the coup, the structural, institutional, economic and historical causes of the coup, and the actors that promoted and justified the coup; in this context, the CV shall analyze and identify, inter alia, foreign interests that appeased and supported the coup.

- $\quad$ The CV shall make proposals for victims to be able to assert their right to the truth, to justice and to remedies. The CV shall formulate recommendations that permit remedies for the victims, establishing measures, both individual and collective, for non-repetition, for restoration of rights, for redress, for rehabilitation and for compensation.

- $\quad$ The CV shall identify each state institution's role in and linkage to the coup and human rights violations, whether by acts or by omissions. The $\mathrm{CV}$ shall thereupon make recommendations for removal from state institutions of all those persons who promoted or participated in the coup and who permitted or participated in human rights violations. The $\mathrm{CV}$ shall identify the corresponding civil and criminal responsibility.

- $\quad$ The CV shall write a report containing all of the preceding elements, which report will be presented to the Honduran people and to state institutions, in order that they may take up the recommendations, and the $\mathrm{CV}$ shall then distribute the report widely within the international community, in particular to the United Nations, the OAS, the European Union, and the International Criminal Court.

- A standing international body shall then be established to monitor, observe, take action, and provide the necessary advice to ensure compliance with the recommendations of the Truth Commission. 


\section{Appendix 3 - Two Emblematic Urgent Actions Released by COFADEH on March 7, 2011}

\section{Leo Valladares Lanza}

\section{Committee of Relatives of the Detained and Disappeared of Honduras (COFADEH)}

\section{URGENT ACTION:}

\section{Human Rights Defender in Danger}

With great concern, the Committee of Relatives of the Detained and Disappeared of Honduras (COFADEH) informs the national and international community of acts of harassment, persecution, and psychological aggression against Mr. Leo Valladares Lanza, the former Human Rights Commissioner of Honduras and the current director of the Association for Participatory Citizenship (ACI Participa).

The 21 of February, 2011 at 3:15pm, a taxi arrived at a private meeting Mr. Leo Valladares Lanza had with the Special Prosecutor for Children Nora Urbina. This same taxi had for some time been parking outside of Mr. Valladares' home, and followed him to the café where he was meeting with the Special Prosecutor and parked outside, where the driver made several calls on his cellphone. The situation was so alarming that neighbours informed the Valladares family of what was happening, and the Special Prosecutor requested an escort for him to return home.

On March 1st, the same taxi parked outside of the Valladares home, but this time was accompanied by another vehicle. The family called the police, who arrived and summoned the drivers of the vehicles in question. Following their inquiries, the police recommended to the family that they leave for a time and take additional security precautions.

Since the second week of February, unknown individuals have called the Valladares residence numerous times asking for "Rodrigo," referringg to José Rodrigo Valladares Pineda, Mr. Valladares' young son who was murdered January 25, 2009 and who's death remains in impunity. After asking for him, the caller laughed menacingly. There has also been an unknown motorcycle making rounds near the residence and accelerating its motor in front of the house to such an extent that it activates the house alarm.

The above mentioned events occurred after Mr. Valladares participated as a speaker during a television program regarding the repositioning of the Armed Forces, the resurgence of militarism in post coup d'état Honduras, and the incorporation of the military in the structures of the Executive Powers of the State.

\section{Background:}

In his role as national Human Rights Commissioner, during his first year in office Mr. Leo Valladares Lanza presented a preliminary report on Disappeared Detainees. During the second year of his term, he presented a report on arbitrary and summary executions and another regarding the 
state of freedom of expression in Honduras. During his final term in office, unknown assailants violently entered his homee, beat his son Rodrigo and his wife Daysi Pineda, and apparently stole a vehicle which was abandoned two blocks from the house.

\section{We request that the national and international community urge the Honduran State to:}

- initiate an independent, impartial, and exhaustive investigation into the threats against Mr. Leo Valladares, that they make public the results of the investigation, and that the responsible parties appear in court;

- take immediate measures to provide effective and appropriate protection to Mr. Leo Valladares according to his wishes;

- carry out its responsibility to guarantee human rights defenders their right to carry out their work without unjust restriction and without fear of reprisal, as is established in the UN Declaration on Human Rights Defenders as well as the resolutions of the OAS.

$<<>>$

II. Trinidad Sánchez Argueta

Committee of Relatives of the Detained and Disappeared of Honduras COFADEH

\section{Urgent Action:}

\section{Human Rights Defender Threatened and Given Ultimatum}

The Committee of Relatives of the Detained and Disappeared of Honduras (COFADEH) expresses its grave concern for the continued attacks against Human Rights Defender Trinidad Sánchez Argueta, Executive Director of the Network for Alternative Community Trade (Red COMAL) based in the city of Siguatepeque in the central department of Comayagua, at $149 \mathrm{Km}$ from the capital city of Tegucigalpa.

On the 25th of February, 2011, at 8:13pm, José Trinidad Sánchez received a text message on his cellphone with the following text: "Trinidad WE KNOW WHERE YOU ARE YOU LIVE IN EL PORBENIR your days are limited so enjoy what you have robbed from Comal as of today count down your days you are being watched you dog."

This is not the first act against Trinidad or the members of his family. In August, 2010, his 25-yearold son Jorge Luis, who was studying in the high school "Republic of Cuba" in the department of Santa Bárbara was detained and subject to mistreatment by agents of the Preventative Police who accused him of being Cuban. After hitting his head against a wall, handcuffing him and throwing him against the sidewalk, they expelled him from the department and ordered him not to return. 
In May 2010, an armed man dressed in black and carrying a number of instruments hiking/mountaineering violently entered Trinidad's home at 2:45am, threatened and removed the family members from their beds, pointed the firearm at them intimidatingly for several minutes, then took a camera and a computer monitor and left.

On November 28, 2009 at 1:40pm, a group of 50 individuals including uniformed police officers, police in civilian clothing, and military personnel violently entered the offices of Red COMAL located in the village of 3 de septiembre in the municipality of Siguatepeque and forced the watchman to open gate to the main building. Once inside, the individuals proceeded to break open the locks on the doors of various offices, including those of the School of Solidarity Economy Training Center.

The contingent, commanded by police captain Freddy Lagos Sánchez, supposedly acting as Executing Judge of a search warrant (authorized by Public Attorney Elizabeth Orellana Rodríguez), proceeded to remove work documents and computer equipment from the offices. Months later, due to pressure from human rights organizations, the Public Attorney returned the apprehended items.

COFADEH is deeply concerned by the situation faced by TRINIDAD SANCHEZ, especially in light of the pattern of systemic attacks against human rights defenders and social activists, particularly with respect to serious incidents registered in the last few months of home invasions, criminal attacks, and illegal entry into offices of human rights organizations. In the last two months three offices have been attacked and one human rights defender has had to leave the country due to reiterated death threats and continued persecution.

COFADEH requests that the national and international community urge the Honduran State to implement the necessary measures and mechanisms to effectively guarantee and protect the life and integrity of JOSE TRINIDAD SANCHEZ. The State must equally guarantee the Right to Defend Human Rights, as stated and universally recognized by the UN Universal Declaration on Human Rights Defenders, ratified in 1998, and the 1999 and 2000 resolutions in the OAS on human rights defenders in the Americas.

Tegucigalpa, March 7, 2011 


\section{Appendix 4 - Extracts from October 2010 HIVOS Report}

The next approximately 25 pages (pp 19 - 46) consists of the extracts prepared by Craig Scott from the Spanish-language report, Reina Rivera Joya, IMPUNIDAD EN HONDURAS (Post Golpe de Estado del 28 de junio de 2009): LINEAMIENTOS GENERALES PARA SU ABORDAJE

(Octubre 2010, HIVOS/ Instituto Humanista de Cooperación al Desarrollo), and tabled with the Standing Committee on Foreign Affairs and International Development in advance of the March 9, 2011, hearing. It appears below in two versions, firstly the English translation by the Parliament of Canada and secondly the original Spanish. The French translation prepared by the Parliament of Canada will be published online at:

http://www2.parl.gc.ca/CommitteeBusiness/StudyActivityHome.aspx?Cmte=FAAE\&Language= E\&Mode $=1 \&$ Parl $=40 \&$ Ses $=3 \&$ Stac $=3806929$.

The versions thus appear in the following order:

- Reina Rivera Joya, Impunity in Honduras (Post Coup d'Etat June 28, 2009):

General Guidelines for Engagement (October 2010, HIVOS/ Humanist Institute for Development Cooperation)

pp 19-32

- Reina Rivera Joya, Impunidad en Honduras (Post Golpe de Estado del 28 de Junio de 2009): Lineamientos Generales para su Abordaje (Octubre 2010, HIVOS/ Instituto Humanista de Cooperación al Desarrollo)

pp 33- 46

\footnotetext{
"Note that I prefer the sub-title of "Guidelines for Approaching the Subject" as a translation from the Spanish, but the present sub-title is the official Parliamentary translation.
} 


\title{
HIVOS / Humanist Institute for Development Cooperation
}

\section{IMPUNITY IN HONDURAS (Post Coup d'Etat June 28, 2009): GENERAL GUIDELINES FOR ENGAGEMENT}

\author{
Prepared by: Reina Rivera Joya ${ }^{3}$ \\ October 2010 \\ Tegucigalpa, Honduras
}

\section{INTRODUCTION}

On June 28, 2009, a coup d'etat took place in Honduras that resulted not only in the overthrow of the democratically-elected President and a breach of constitutional order, but also had a serious impact on the already precarious human rights situation. With the coup, claims of violations became serious and widespread. This saturated the human rights defence organizations' ability to protect and defend, in that the public institutions created for such purpose lost all legitimacy by not only validating the constitutional breach, but also denying human rights violations (such as the case of the Honduran ombudsman) and responding ineffectually in the case of other authorities, particularly in the legal sector.

The report by the Inter-American Commission on Human Rights (IACHR), entitled Honduras: Human Rights and the Coup d'Etat, affirms that hundreds of precautionary measures were issued to safeguard life and personal security as a result of the post-coup repression. Further, the Commission indicates: "Along with the loss of institutional legitimacy brought about by the coup d'etat, during its visit the Commission confirmed that serious human rights violations had been committed, including killings, an arbitrary declaration of a state of emergency, disproportionate use of force against public demonstrations, criminalization of public protest, arbitrary detention of thousands of persons, cruel, inbuman and degrading treatment, poor detention conditions, militarization of Honduran territory, an increase in incidents of racial discrimination, violations of women's rights, severe and arbitrary restrictions on the right to freedom of expression, and serious

\footnotetext{
${ }^{3}$ This document consists of extracts from a 60-page consultant's report that was distributed in October 2010 (only in Spanish) by the Dutch non-governmental organization HIVOS (www.hivos.org). The extract is 10 pages. The selections were made by Professor Craig Scott of Osgoode Hall Law School, who is also a Commissioner with the (non-governmental) Truth Commission in Honduras (www.comisiondeverdadhonduras.org). The extracts chosen from the HIVOS report are treated as a working hypothesis with respect to Professor Scott's contribution as part of the Truth Commission. As of March 2, 2011, the report still does not appear on the HIVOS website. To obtain the full report in Spanish, Professor Scott can be contacted by e-mail at cscott@osgoode.yorku.ca. HIVOS has granted permission to prepare this 10-page extract for presentation - that is, to present the French and English translations - to the Canadian House of Commons Standing Committee on Foreign Affairs with respect to the hearings that will be held on March 9, 2011. (Post-translation note from Professor Scott: This official translation from Spanish to English has been prepared by the Parliament of Canada.)
} 
violations of political rights. The Commission also established that judicial remedies were ineffective in protecting buman rights." (IACHR, 2009:7).

... This document is a starting point from which to show HIVOS the scenario around the human rights situation and the pending challenges for action in terms of human rights and impunity in Honduras. ...

... The information gathered illustrates the current state of human rights violations in Honduras, the stagnation and inaction on the part of the national justice system to investigate and take legal action, the key actors and factors that contribute to the impunity or that struggle against it, and finally offers some recommendations for more in-depth work on this matter.

\section{THE SCENARIO AROUND HUMAN RIGHTS IN HONDURAS}

The switch from the de facto regime that usurped power by armed means to the transition government led by Porfirio Lobo Sosa (January 27, 2010) has not involved any improvement in rebuilding the ever-weakening Honduran democracy. The current president was in fact elected despite the contempt of a broad segment of the country that disavowed the electoral process that took place in the midst of the dictatorship and political opposition repression. The opposition had no opportunity for equal participation and demanded that first the democratically-elected President be restored and that the political and military leaders who usurped power be removed from exercising authority.

In those elections, only the presidential face of the de facto governor Roberto Micheletti was subject to change. The visible faces that carried out and/or legitimized the coup d'etat continue in positions of power, most of whom held positions of power in the Supreme Court, the Office of the Attorney General, the Audit Office, the Office of the Ombudsman and National Congress. Many others, primarily the leaders of the armed forces, were placed directly by Lobo Sosa himself in strategic public service positions, using the argument of forming a national Unity and Reconciliation Government from among the well-known Honduran plutocracy.

Internationally, several countries have still not re-established relations with Honduras, which continues to be suspended from the Organization of American States (OAS) and the Central American Integration System (SICA), even though the new government is attempting, with the backing of the United States, to rejoin these organizations, which will open doors for it to receive international financial assistance.

The Union of South American Nations (USAN) objects to such a return, noting that an electoral process is not enough to demonstrate that Honduras is in compliance with the Inter-American 
Democratic Charter. There is no evidence of serious efforts to put an end to the impunity of the coup d'etat, which is seen as a serious precedent for democracies in Latin America....

The coup also tore the social fabric in Honduras and undermined the foundations of representative democracy. The country became polarized and the controversy continues to be opposition to convening a National Constituent Assembly and the issuance of a new Constitution... In that context, one positive aspect of the crisis is the intense debate and mobilization that arose around the need for an in-depth review of the democratic model in Honduras.

$\cdots$

The expression of this social mobilization is the National Front for Popular Resistance (FNRP), a popular organization that to date acts with complete political and ideological independence from political parties and is made up of popular movements, social organizations, political bodies, NGOs, micro, small and medium-sized business owners, environmental and student movements, the national teachers federation, human rights groups, young people, women, artists, intellectuals, indigenous and black communities, the lesbian, gay, bisexual and transgender (LGTB) community, popular reformist churches and other organized and non-organized sectors, emerging as the largest progressive force in the country. As of September 15, 2010, in 5 months it had collected over 1,342,876 signatures from persons over the age of 18 to self-convene a National Constituent Assembly; in other words, almost $30 \%$ of the voters list, estimated at close to 4.6 million voters, of which nearly a million are abroad.

As a result of the coup d'etat, despite the significant social power it represents, the National Front for Popular Resistance had to deal with media defamation, military intelligence describing it as a potential insurgent group, and judicial and political persecution. Further, its members are generally the main victims of human rights violations committed in the country, in a scenario of worsening civil insecurity, to the extent that the country is approaching the alarming rate of 66.8 murders per 100,000 inhabitants - one of the highest on the continent. This only facilitates the façade for the government not to be held responsible for crimes against journalists, campesino leaders, unions, teachers, human rights defenders and FNRP activists, which increases the chance that impunity for human rights violations will be consolidated.

\section{STATUS OF HUMAN RIGHTS VIOLATIONS IN HONDURAS ${ }^{4}$} $\cdots$

\footnotetext{
${ }^{4}$ NOTE from Professor Scott: For reasons of space (the translation of this document is limited to 10 pages), I am omitting large sections on the extrajudicial executions, torture, illegal and arbitrary detentions, threats to personal security and violations of freedom of expression and the media. These are welldocumented by multiple sources (and therefore available to the Standing Committee separately), while the situation described below (in the section I kept) is not as well-known.
} 


\subsection{Violations with respect to defending the right to land, the environment and other natural resources.}

Ever since the early 1990's in Honduras, with structural adjustment measures applied to the economy and the neoliberal model expanded through globalization, there began a process of agrarian counter reforms, of granting concessions to natural resources - even in protected areas and land owned by indigenous and Afro-descendant communities.

The growth of such neo-colonization projects was facilitated by legal reforms, including to the text of the Constitution to appropriate land subject to collective and community trusteeship rights.

Some of these appropriations have triggered serious tensions. This is the case with the area known as Bajo Aguán, where ever since the early 1990's, a process began of buying and selling landholdings that are protected under the Law regarding the Modernization and Development of the Agricultural Sector, and which concluded with the sale of the assets of 40 campesino companies to the powerful businessman Miguel Facussé, as well as others like René Morales, Reinaldo Canales and other landowners with less economic and political power in the region. Because the sale of lands established under the Agrarian Reform Law violated procedures, these transactions are still under investigation (FIAN, May 2010: page 3).

The FIAN Honduras report indicates that since 2001, 28 campesino cooperatives formed the United Farm Workers Movement (MUCA) to reclaim their right to the land. During Manuel Zelaya's government, a tripartite commission was formed between campesinos, landowners and the government in order to resolve the conflict. The landowners undertook to review the legality of land ownership and even agreed to remediate the occupied lands, 18 irrespective of the results obtained from investigations into the legality of the sale of such lands (FIAN, May 2010).

This process was interrupted by the coup d'etat, reviving tensions that have already cost the life of 11 campesinos and 3 security guards in 2010. Porfirio Lobo Sosa's government signed an agreement in April 2010 with 24 organizations belonging to MUCA, in a climate of extreme militarization of the lands occupied by the campesino groups. To date the agreement remains unfulfilled; not all of the lands agreed upon have been handed over and 152 arrest warrants are in force against campesinos for possession of lands that paradoxically form part of the political agreement with the government.

Similarly, claims have been made against unauthorized landowner groups and private security guards operating in the area that have carried out attacks on campesinos, with the numbers of dead being recorded. Claims have also been made regarding the presence of possible Colombian paramilitaries hired by the businessmen Facussé, Morales and Canales. In terms of the oligarchy in the area, it accuses the campesino groups of being guerrillas receiving support from international 
terrorist organizations, while in its various communiques the Honduran Human Rights Platform establishes the extreme poverty in which the campesino population lives in the Aguán region.

\section{MOST COMMON PATTERNS IN HUMAN RIGHTS VIOLATIONS}

In human rights, patterns are the combination of events and circumstances that are repeated, indicating the essential features of the modus operandi for carrying out human rights violations, the profiles of victims or aggressors, the categories of rights violated and other circumstances that become typical. However, events that seem to be isolated can also reveal patterns with respect to events that are known in other contexts and reflect that it is a repeat.

In general, the following are the main patterns that characterize human rights violations in Honduras:

- Most of the time, the victim profile includes human rights defenders[,] women's rights activists, LGTBI activists, environmentalists, union leaders, campesino organizations, journalists, National Front for Popular Resistance activists or their family members, Resistance Lawyers' Front litigants or defenders, NGO social leaders, student organizations and mass media companies (radio, television, press, including alternative and community mass media). $\cdots$

- Repression as a method: In various types of violations there is direct, verifiable participation by government agents. These include attacks during demonstrations that result in death, the excessive use of force, including the use of lethal weapons and instruments that cause pain and torture.

- In social rights violations, direct government responsibility is verifiable through both action (concessions, passing of laws, issuing of administrative or judicial rulings) and omission, tolerance or acquiescence toward groups with political, economic and other de facto power.

- In several different types of violations, we can see patterns of surveillance, harassment, threats, anonymous calls, threatening messages and raids that look like theft in homes and workplaces. Some of the threats reflect hatred for the person's political position or discrimination with respect to gender, sexual orientation or financial situation.

- Use of clandestine detention facilities. There are also indications that four clandestine operations centres exist (only in the capital's Central District), where victims are mistreated[,] interrogated and then abandoned in a quiet street (Committee of Relatives of the Disappeared in Honduras (COFADEH), 2010: 30).

- Granting precautionary measures does not guarantee greater protection against attacks on life or death threats, which persist even after the government is notified of its duty to protect the person. 
- In cases where the responsibility for human rights violations is clear, it has been seen that all armed groups in the country are involved (all branches of the Armed Forces, the National Police and all of its offices, the Municipal Police in the country's main cities, guards from private security companies). This is an indication of the repressive nature of officials.

- In the case of anonymous assailants, human rights organizations note that they have detected a profile of aggressors that could belong to clandestine bodies or parallel powers since special training has been noted, including surveillance, special weapons handling, type of weapon used, method of attack, the physical build of the aggressors, and some survivors refer to recognizing military jargon in conversations and have detected foreign accents, particularly from South America (COFADEH, 2010). Such apparatus or clandestine bodies could be inherited from the clandestine government structures that have gone unpunished (for example Battalion 3-16, which was created by the late General Álvarez Martínez and operated during the repression in the 1980's). Although such parallel structures seemed to have been dismantled, members were never purged from the police and military, and today many have reached the uppermost ranks within those institutions. All of the above points to the establishment of new apparatus or clandestine bodies that are operating in coordination or in line with agents from special official organizations. Their participation has been detected in certain attacks, in threats and agent infiltrations from the Cobra Command Strike Force, the Presidential Honour Guard, the Special Kidnapping Unit, the Preventative Police Analysis Unit, the Communications Battalion, etc. The Inter-American Commission has confirmed the existence of such groups... (IACHR, June 2010: page 31 [sic])

- In extrajudicial executions, the use of hired assassins with or without ski masks has been observed. Gang members have also been hired to carry out the attacks.

- Many attacks are in public, in the victim's home or workplace, from moving vehicles (some luxury models) and motorcycles.

- Some of the victims were intercepted and detained/disappeared for a few days until their bodies were found.

- Some of the victims were administratively detained by the police in the days prior or in recent months.

- The state of the bodies reflects brutality, torture, temporary confinement (possibly for interrogation) and extrajudicial execution by several shots from a high-calibre gun primarily in the head. The body sometimes appears with hands and feet tied, and tends to be abandoned on the outskirts of communities - farms, scrubland and highways.

\section{FACTORS THAT CONTRIBUTE TO IMPUNITY IN HUMAN RIGHTS ... 5.1 IMPUNITY FACTORS IN HONDURAS}

\section{a) Regulatory Factors:}


... In its March 2010 report regarding human rights violations in Honduras since the coup d'etat on June 28, 2009, the United Nations Office of the High Commissioner for Human Rights recommended to "revise or abrogate national legislation incompatible with international standards, in particular provisions on crimes of sedition, illicit demonstrations, freedom of expression, political and electoral rights, torture, independence of the judiciary, the Police and Social Coexistence Law, and the State of Emergency Law."

Other provisions that facilitate the violation of human rights are reforms to the Code of Criminal Procedure to expand the use of preventive detention and limit the application of diversion measures; the proposal by those responsible for justice to reduce the age a minor can go into an adult prison to 16; the validity of legislation that encourages detention for suspicion of, for example, criminal conspiracy; the Police and Social Coexistence Law, which authorizes administrative detention for mere suspicion or the detaining of people for vagrancy, which directly applies to young students, the LGTBI population, commercial sex workers, or based on clothing or appearance. Specific reference must be made to the regulations that favour criminalizing public protest through offences such as sedition, terrorism and illegal protest.

In addition there is a failure to define the crime of forced disappearance or determine a better, more precise definition of the crimes of torture, sexual exploitation and discrimination (Report from the nongovernmental organizations of Honduras to the EPU: 2010).

\section{a.1) The specific case of the Amnesty Decree.}

One special case of regulatory impunity in Honduras is the passing of the Amnesty Decree (2-2010) by the de facto regime's National Congress on January 26, 2010, signed by President Porfirio Lobo on the same day as his rise to power, January 27, 2010, and which was quickly published in the Official Gazette on February 2, 2010 and came into force on February 22.

Such decree was originally proposed in the Tegucigalpa-San José Accord by the President of Costa Rica, Oscar Arias, in order to restore President Zelaya to power in August 2009. The existence of amnesty was rejected by the de facto regime and President Manuel Zelaya himself, which is why it does not appear as part of the final text of the Guaymuras Accord...

Despite the fact that amnesty ceased to be part of the failed accord, the elected representatives who remained in their positions during the de facto regime passed an amnesty decree that included crimes such as treason, crimes against the form of government and changes to the form of government via force or legal means;...

The text of the decree indicates that it does not apply to buman rights violations or to the crime of corruption. Although the whereas clause of the decree sets out that its mission is to reconcile the Honduran family and approve the violations of law attributed to Manuel Zelaya for his alleged continuist intentions by attempting to convene a Constituent Assembly 19, the truth is that those who benefited most were the same elected representatives who on June 28, 2009 issued a decree against 
the Constitution, removing President Zelaya, with no authority to do so, using the Armed Forces to kidnap him and appointing Roberto Micheletti (then Speaker of the National Congress) in his place.

In subsequent statements, deposed President Manuel Zelaya stated that he had no interest in availing of such amnesty decree since his actions to convene a consultation to ask the people whether they wanted a Constituent Assembly were not illegal and the court cases against him were null and void for having been initiated after the coup d'etat, when the country was subjected to a dictatorship.

... The practice of applying this decree has meant the highest civilian and military authorities who participated in the coup d'etat, as well as the de facto civil society groups that participated in such conspiracy, remain unpunished.

In the very cases of human rights violations, like the crimes against the mass media (which, given the lack of an express criminal concept were taken to court for abuse of authority), the Office of the Attorney General itself applied for their dismissal under the amnesty. The arbitrary detentions, cruel and inhuman treatment and the ban on extraditing or expatriating persons considered under international human rights treaties were subject to this manhandling of the legislation by being granted amnesty, and such violations were interpreted merely as acts of abuse of authority subject to amnesty.

Political prisoners and those sought by the state for demonstrating against the coup were humiliated by the judges when amnesty was applied to them, describing them as terrorists, seditious or rebels (political crimes). Such regulatory anomaly makes it impossible to reclaim the rights of political prisoners, particularly the right to be considered innocent, to a fair trial (particularly to clear their name), to take part in demonstrations, the right to freedom of opinion, the right to resist and rebel against coups d'etats as provided for in Article No. 3 of the Honduran Constitution....

\section{b) Political-institutional factors in impunity in Honduras}

\section{b.1 Lack of independence in the judicial system and official mechanisms to protect human rights.}

Historically, the Honduran justice system tends to be described by opinion polls as corrupt and politicized...

Pursuant to the report on the Preliminary Observations of the IACHR on its visit to Honduras May 15 to 18: "As the Commission found during its May 2010 visit, the buman rights violations persist, as does the impunity. From what the Commission observed, the situation is due to a number of factors. The authorities charged with investigating, prosecuting and punishing the guilty continue to systematically deny the existence of buman rights violations, which results in inaction, tolerance and even dismissal of any charges against those who carried out the coup d'etat and the aforementioned violations... Furthermore, the Commission observed that in this context of impunity, there is no proceeding calculated to ensure a public and transparent procedure for the selection and election of 
candidates for high positions within the system for the administration of justice. Although some officials in the justice system may want to conduct a proper investigation, they do not have the necessary means because the National Police, which is in charge of criminal investigation, has neither the capacity nor the preparation needed, and corruption is said to be rampant within its ranks." (IACHR: June 2010, pages 22 and 23 [sic]).

\section{b. 2 Justice system actors and their role in impunity in Honduras.}

b.2.1 The National Commission for Human Rights (CONADEH), which is the constitutional institution created to guarantee the rights and freedoms recognized in the Constitution, as well as the Treaties, Covenants, Agreements and Optional Protocols ratified by the Honduran government. ... The Commissioner was re-elected in 2009 for a 6-year period, his mandate ending in 2015.

... [T] he situation of defencelessness in the country was consolidated when the Commissioner for Human Rights, Ramón Custodio, denied that there had ever been a breach of constitutional order, defended the legality of the de facto regime's decrees regarding states of emergency and curfews, justified shutting down the media (because they inspired sedition and law and order had to be maintained) and rejected the existence of human rights violations, so that the few claims people could have filed with this organization were not duly processed....

In this regard, in its December 30, 2009 report, the IACHR states: "The Commission is concerned by the news regarding the role played by National Commissioner of Human Rights, Ramón Custodio López. By denying the existence of the coup d'etat he prevented the inhabitants of Honduras from gaining access to an independent mechanism for the protection of their human rights."

The National Commission for Human Rights has described the communiques and reports from the IACHR as being manipulated and the objective of which is to harm Honduras, in order to scare off foreign investment...

\section{b.2.2 National Police internal control mechanism.}

... During the coup d'etat, the Armed Forces and the National Police were the primary perpetrators of blatant human rights violations; all of their branches and agencies were involved, without exception. The internal control mechanisms in both the Honduran National Police and the Armed Forces (Office of the Inspector General, Internal Audit and even a Directorate of Human Rights and Humanitarian Law) failed to do their duty and even actively participated in planning the violations, because the de facto regime called upon all police and military units to defend democratic order....

\section{b.2.3 The Office of the Attorney General, with special reference to the Office of the Special Prosecutor for Human Rights}


The Office of the Attorney General is the constitutional institution responsible for acting on behalf of victims in a criminal action. The Office of the Public Prosecutor, as it is often called, has an exclusive monopoly over criminal action. In other words, in crimes of law and order only it has the key to open a criminal indictment, which is why its independence and effectiveness in the investigation is fundamental for the fight against impunity....

In the case of the Honduran Office of the Public Prosecutor, those at the highest levels have been indicated as being jointly responsible for the coup d'etat and having forged indictments ex post to legitimize the military kidnapping and exiling of President Manuel Zelaya....

The role of the Office of the Public Prosecutor was not only to whitewash the coup but its monopoly over criminal matters also allowed it to launch its entire institutional machinery to persecute the emerging resistance to the coup d'etat. Over 200 court cases were recorded throughout the country (some cases involved group charges, such as the one in which 57 campesinos took over the National Agrarian Institute), including charges against officials from Manuel Zelaya's Executive Branch, guaranteeing their exile and no return if the constitution was restored, charges against mayors who were part of the resistance, teachers federation leaders (the highest number charged) and demonstrators from the movement that arose as a result of the coup[,] the National Front for Popular Resistance. Charges ranged from corruption (against mayors loyal to Zelaya and his ministers), money laundering and receiving funds from Venezuela and the Revolutionary Armed Forces of Colombia (FARC) (sent to leaders from the Front), terrorism, sedition, damage, illegal protest. Such charges were quickly brought to trial, arrest warrants issued, the people jailed and, despite the amnesty, people are in some cases still defending themselves from the same.

This did not happen with human rights violations. The Office of the Special Prosecutor [for Human Rights] was described as slow and tolerant. Apart from its failure to accuse the leaders responsible for the crimes, it did not ex officio exercise outside control over the illegal decrees that established the state of emergency and curfews and it did not take action to seize weapons the police and army were not allowed to use against demonstrators (such as pepper spray, pipes, baseball bats, clubs, chains and other weapons not regulated by international standards for such purposes).

For example, the Centre for the Prevention of Torture and Treatment and Rehabilitation of its Victims and their Families (CPTRT) filed 35 claims of torture and mistreatment before the Office of the Public Prosecutor for Human Rights, while the Resistance Lawyers' Front reported 46 claims for similar events. COFADEH states that it took almost all of its cases to the Office of the Public Prosecutor for Human Rights. However, more than a year and a half later, only a dozen cases have been filed, most for misdemeanours such as abuse of authority or breach of official's duties that are categorized as being to the detriment of public service and not the victim (an interpretation that 
devalues the seriousness of the human rights violations), and makes it easier to apply amnesty to human rights violations.

... Incumbents in the Office of the Attorney General were elected in 2009 for a 5-year period, their mandate ending in 2014.

\section{b.2.4 The Judiciary}

... During the coup d'etat, the Honduran Judiciary created prior favourable conditions such as issuing legal rulings to stop the public consultation on the Constituent Assembly. Four days before the coup, in record time, the court sitting en banc ordered that the head of the Armed Forces, Romeo Vásquez Velásquez, be reinstated to his position (removed by President Zelaya, as an official he is free to appoint pursuant to his constitutional powers). The Armed Forces, led by General Vásquez, carried out the armed attack on President Zelaya's residence; they kidnapped him in the early hours of the morning and exiled him from the country on an Air Force plane....

Like the Office of the Public Prosecutor, top Supreme Court personnel are responsible for whitewashing the coup d'etat by issuing forged documentation after the coup, such as the arrest warrant presented to the press 3 days after the coup (but not to the president on the morning he was taken into custody). The highest court became a party to the theory of constitutional succession in Honduras and supported Roberto Micheletti in his dictatorship that lasted several months by issuing communiques calling upon staff to take part in public demonstrations planned by those who usurped power.

Further, the Supreme Court, judges and subordinate magistrates impeded the investigation, prosecution and punishment of crimes for breach of democracy and human rights violations. In the few trials commenced for human rights (12), the judges of lower courts hurried to issue final rulings in the proceedings. Meanwhile, trials remain open against campesinos, union leaders and officials from the deposed government, including former President Zelaya himself, who lives in exile.

According to the IACHR, "The widespread impunity that attends buman rights violations is due in part to the Supreme Court's decisions, which undermine the rule of law." In this regard, the Commission has seen dismissals issued in favour of those who helped bring about the coup d'etat or who committed crimes during the same... "Apart from the questionable role that the Supreme Court played during the coup d'etat, since then it has acquitted the military accused of participating in the coup but has dismissed judges and magistrates that endeavoured to avert the coup by democratic means." (IACHR, June 2010, paragraph 95). \{Note 24: "On January 26, 2010, hours before Porfirio Lobo was sworn in as Honduras' new President, the special judge and President of the Supreme Court, Jorge Rivera, dismissed the charges against the accused military chiefs."

For human rights organizations, the violations of independence are also quite serious - particularly the manipulative and arbitrary appointment, transfer and removal of judges and magistrates. The most serious action was the dismissal of three judges, one magistrate and one public defender 
affiliated with the Association of Judges for Democracy for having issued opinions, even of an academic nature, against the coup d'etat....

Similarly, the human rights special appeals contained in the Constitution and the Law regarding Constitutional Rights such as Habeas Corpus, Unconstitutionality and Amparo ${ }^{5}$ have been ineffectual before the Constitutional Chamber of the Supreme Court. Overall, there is condemnation for their late rulings, as well as for issuing rulings that transfer competent jurisdiction for rights protection to longer administrative trial proceedings.

According to a report prepared by The Centre for Research and Promotion of Human Rights (CIPRODEH), from June 28 to October 2009, 87 amparo proceedings were filed against various actions and are in the review phase.

There are 15 magistrates in the Supreme Court and they were elected in 2009 for a 7-year period, their mandate ending in 2016. The magistrates of this high court are not allowed to enter the United States or a number of countries in the European Union.

\section{SOCIAL FACTORS}

... c.1 De facto powers in Honduras. The Spanish term poder fáctico [de facto power] is defined by the Royal Spanish Academy as ["] segment of society outside the political institutions that exercise great influence over them, based on the ability to exert pressure. For example, banking, private enterprise, the Church, the military, the media, drug trafficking, etc."

... The de facto groups in Honduras consist not only of the business, industrial and banking sector, but also the so-called mandaderos or groups that are influenced by them and ultimately negotiate cushy jobs and protection. These include the military (which for over two decades has made inroads into large companies, including the banking sector), church leaders and the political party elite, with whom agreements are made on the manner and way in which to obtain power and profit from the government and society....

When Manuel Zelaya's took power in 2006, these groups, as always, claimed their share of power. After several clashes, the deposed president publicly stated that he didn't hold the real power in Honduras but was coerced by large media corporations who abused freedom of expression to blackmail and hold the government captive.

From the beginning, Zelaya's government backed the clashes with some of the most powerful groups in the country. Specifically, when the government acted autonomously to buy and import fuel, it distanced itself from the oligopolies that held public utility concessions in telecommunications, electricity and construction. It even chose to create an official government

\footnotetext{
${ }^{5}$ Translator's Note: "Amparo" refers to a petition for constitutional relief that can be filed to challenge government action.
} 
television channel and approve an over $62 \%$ increase in the minimum wage vis-a-vis the $8 \%$ that business owners were offering.

The de facto groups would become the ideologues of the June 2009 coup d'etat, as a mechanism to maintain their historical political authority. Through the National Congress, they co-opted the appointment of the highest authorities in the Judiciary, the Office of the Public Prosecutor, the Audit Office and CONADEH, all of whom were elected in early 2009 through their visible influence (private enterprise made up the board nominating the election of magistrates) and underground influence....

In early 2009 and vis-a-vis the pro-constituent assembly consultation, the de facto groups were required to make public appearances - not their usual behaviour. Therefore, prior to the coup d'etat they decided to organize (and still finance) several associations. These include the Democratic Civic Union (UCD), the Peace and Democracy Group, the student group Generation X for Change, all in charge of doing the dirty work of destabilizing the government in power. This is what they did with Zelaya until he was overthrown and they are now doing it with media campaigns aimed at Porfirio Lobo, who has denounced attempts by these groups to overthrow him.

... In summary, the de facto powers in Honduras are those who hold real power in the government and its institutions. Their capacity to influence is such that, in the history of Honduras, not one person or corporation with direct ties to these groups has faced justice. They live a life of selective impunity, which guarantees them a complete absence of punishment as the segment that holds real power and is extremely dangerous in terms of potential alliances as a result of the financing and protection they can obtain from organized crime.

\section{c.2 Militarization}

... In Honduras, the Doctrine of National Security implemented during the Cold War was the theoretical framework for military authority relationships, wherein civil authority and its institutions voluntarily and willingly submit to its strength and values, with the consequent weakening of government institutions and therefore the democratic rule of law.

The Central American peace processes and the signing of the Framework Treaty on Democratic Security in 1995 resulted in a gradual withdrawal of the military from its hierarchical position within civil authority, in a reduced fiscal budget the first few years after said treaties were signed and in its withdrawal from strategic positions in the government. However, this did not mean it abandoned its privileged social and economic position through its role as powerful businessmen in domestic banking, the cement industry, private security and arms sales, where it has a captive market and monopoly as the primary beneficiary of the growing wave of violence in Honduras.

It is precisely the topic of civil insecurity that "justified" the Honduran military's reappearance in the country's social and political scene. Given a civil authority that was weak and afraid of the 
increase in organized crime, the military were called on to once again participate in street patrols, to assist with intelligence, to provide support for criminal investigation work and to control sea, air and land space - tasks that should be carried out by the country's civilian forces.... President Zelaya himself favoured re-militarization in Honduras and, given the pressure from de facto groups, it was his strategy to seek the favour of the military authority, which he rewarded by re-electing its commander, Romeo Vásquez Velásquez, who had reached the age of retirement as required by its own charter. He assigned the military tasks such as to "protect" the forest and natural resources, which opened inroads into a new line of corruption, and he called on them to help manage the national electricity company (ENEE)....

On a national level, as of June 28, 2009, the Armed Forces took control of important public offices considered to be strategic and that as of that date fell under the control of the Armed Forces, including the National Police becoming subordinate to the army. Civil society institutions controlled by the militarization include the Honduran Telecommunications Company (HONDUTEL), which provides government telephone services, the Directorate of Immigration, the Honduran Merchant Marine, the Directorate of Civil Aeronautics. The military also holds positions of power in the Honduran Electricity Company, the Permanent Contingency Commission (COPECO) and opened offices in the Secretariat of Security and the Honduran National Congress. \{Note 27: General Romeo Vásquez Velásquez was appointed Manager of the national telecommunications company (HONDUTEL)...\} Its continued presence in the Executive Branch under the name Presidential Honour Guard grew and it has become a civilian intelligence office; several of its members have been detected infiltrating demonstrations and meetings organized by the unions, the popular movement and the National Front for Popular Resistance.

This mode of military administration over civil society institutions was common in the 1970's and 1980's in the midst of the Cold War and makes it easier to consolidate the so-called military establishment in Honduran civilian life and political authority.

... On May 14, 2010, the National Congress passed a decree in which it instructs the Honduran Secretariat of Defence to cooperate with "strictly necessary staff and resources of the Armed Forces in keeping with the way in which each situation unfolds, in order for the National Police to carry out its duties in an efficient and timely manner to re-establish the peace, prevent, control and fight crime." This decree facilitated the militarization of the Bajo Aguán area. Three battalions from other regions in the country moved there to intimidate the campesino movement, using the argument that an insurgency is brewing in the area.

Thus, militarization is a fundamental factor in impunity in Honduras. This is a group with real power that exercises control over the civil authority through submission or fear, including judges and magistrates who are not capable of indicting them. Militarization fosters human rights violations on two levels: first, as direct perpetrators of the same; and second, as a real power in the country's political and institutional order. 


\title{
HIVOS / Instituto Humanista de Cooperación al Desarrollo
}

\section{IMPUNIDAD EN HONDURAS (Post Golpe de Estado del 28 de junio de 2009): LINEAMIENTOS GENERALES PARA SU ABORDAJE}

\author{
Preparado por: Reina Rivera Joya ${ }^{6}$ \\ Octubre de 2010 \\ Tegucigalpa, Honduras
}

\section{INTRODUCCIÓN:}

El 28 de junio de 2009 se produjo en Honduras un Golpe de Estado que tuvo como resultado no solo el derrocamiento del Presidente democráticamente electo y la ruptura del orden constitucional; sino un impacto grave sobre la ya precaria situación de los derechos humanos. Con el Golpe las denuncias de violaciones pasaron a ser graves y masivas lo que ha saturado a las organizaciones defensores y defensoras de derechos humanos en su capacidad de proteger y defender; en tanto la institucionalidad pública creada para ello resulto deslegitimada al no solo convalidar la ruptura constitucional, pues también se llegó a negar las violaciones a derechos humanos como el caso del ombudsman hondureño, o de una respuesta ineficaz en el caso de otras instancias particularmente del sector justicia.

En el informe de la Comisión Interamericana de Derechos Humanos, CIDH, denominado Honduras: Derechos Humanos y Golpe de Estado se afirma haber emitido centenares de medidas cautelares para salvaguardar la vida y la seguridad personal a raíz de la represión post golpe, además la Comisión señala haber constatado: que en Honduras, junto con la deslegitimación institucional originada por el golpe de Estado, se han producido graves violaciones a los derechos humanos, incluyendo muertes, declaración arbitraria del estado de excepción, represión de manifestaciones públicas a través del uso desproporcionado de la fuerza, criminalización de la protesta social, detenciones arbitrarias de miles de personas, tratos crueles, inbumanosy degradantes y malas condiciones de detención, militarización del territorio, aumento de las situaciones de

\footnotetext{
${ }^{6}$ El presente documento consta de extractos de un informe de consultoría de 60 páginas que se distribuyó en octubre de 2010, sólo en español, por la organización no gubernamental holandesa, HIVOS (www.hivos.org). El extracto es de 10 páginas. Las selecciones se han hecho por el profesor Craig Scott, de Osgoode Hall Law School, quien también es Comisionado de la (no gubernamental) Comisión de Verdad en Honduras (www.comisiondeverdadhonduras.org). Los extractos seleccionados del informe HIVOS son tratados como hipótesis de trabajo en relación con la contribución del profesor Scott dentro de la Comisión de Verdad. El 2 de marzo de 2011, el informe aún no está en el sitio web de HIVOS. Para conseguir el informe completo en español, el profesor Scott puede ser contactado por correo electrónico a cscott@osgoode.yorku.ca. HIVOS ha concedido permiso para preparar este extracto de 10 páginas para presentarlo - es decir, presentar las traducciones al francés e al inglés - al Comité Permanente de Asuntos Exteriores de la Cámara de los Comunes de Canadá en relación con las audiencias que se celebrarán el 9 de marzo de 2011.
} 
discriminación racial, violaciones a los derechos de las mujeres, serias restricciones arbitrarias al derecho a la libertad de expresión y graves vulneraciones a los derechos politicos. La CIDH también comprobó la ineficacia de los recursos judiciales para proteger los derechos bumanos (CIDH, 2009:7).

... El presente documento pretende ser un punto de partida para ilustrar a Hivos sobre cuáles son los escenarios en torno a la situación de derechos humanos y los desafíos de acción pendientes en materia de derechos humanos e impunidad en Honduras. ...

... Los datos recabados ilustran el estado actual de las violaciones a derechos humanos en Honduras, el estancamiento y la inacción de la justicia nacional para investigar y sancionar; los factores y actores claves que inciden en la impunidad o que luchan contra ella, y finalmente da algunas recomendaciones para un trabajo más a profundidad en el tema.

\section{EL ESCENARIO QUE RODEA LOS DERECHOS HUMANOS EN HONDURAS.}

El cambio del régimen de facto que usurpo el Poder por la vía de las armas hacia un gobierno de transición rectorado por Porfirio Lobo Sosa (27 de enero 2010) no ha significado una mejoría hacia la reconstrucción de la cada vez más débil democracia hondureña. El presidente actual de hecho fue electo bajo el rechazo de un amplio sector del país que desconoció el proceso electoral realizado en medio de la dictadura y la represión a la oposición política que no tuvo oportunidad de participación igualitaria y que demandaba que previamente se restaurara al presidente democráticamente electo y por ende se separaran del ejercicio del poder a las cúpulas políticas y militares golpistas.

De aquellas elecciones solo el rostro presidencial del gobernante de facto Roberto Micheletti fue sujeto de cambio, en tanto continúan en posiciones de poder los rostros visibles que ejecutaron y/o legitimaron el Golpe de Estado, la mayoría ubicados en puestos de poder como la Corte Suprema de Justicia, El Ministerio Público, el Tribunal Superior de Cuentas, el Ombudsman; el Congreso Nacional; en tanto otros, principalmente la cúpula militar, han sido ubicados directamente por el propio Lobo Sosa en cargos estratégicos de la Administración Pública bajo el argumento de conformación de un gobierno de Unidad y Reconciliación entre la histórica Plutocracia hondureña.

En el plano internacional un amplio sector de la comunidad de países sigue sin restablecer relaciones con Honduras que continua expulsada del seno de la Organización de Estados Americanos, OEA y del sistema de integración centroamericana, SICA; aunque el nuevo gobierno intenta apoyado por el liderazgo de los Estados Unidos la reincorporación a estos organismos que le abren la puerta a la ayuda financiera internacional.

Dicho retorno es objetado por la Unión de países de Sur América, UNASUR, que señalan que el solo proceso electoral no es suficiente para demostrar que Honduras cumple la Carta Democrática de la OEA, pues no se evidencias esfuerzos serios por romper con la impunidad del Golpe de Estado lo que es visto como un grave precedente para las democracias en la región latinoamericana.... 
El Golpe además resquebrajo el tejido social en Honduras y socavo los cimientos de la democracia representativa, el país se polarizo y el tema de controversia sigue siendo la oposición a la convocatoria a una Asamblea Nacional Constituyente y la emisión de una nueva Constitución...En ese contexto, se puede señalar como un aspecto positivo de la crisis, el intenso debate y movilización generado en torno a la necesidad de revisar a fondo el modelo de democracia en Honduras. ...

La expresión de esa movilización social es el Frente Nacional de Resistencia Popular, FNRP, organización popular que actúa hasta hoy con plena independencia política e ideológica de los partidos políticos y está integrado por movimientos populares, organizaciones sociales, instancias políticas, ongs, micro pequeños y medianos empresarios y empresarias, movimientos ambientalistas, estudiantiles, magisterio nacional, grupos de derechos humanos, jóvenes, mujeres, artistas, intelectuales, pueblos indígenas y negros, comunidad lésbica, gay, transexual y bisexual (LGTB), iglesias populares reformistas, y otros sectores organizados y no organizados perfilándose como la mayor fuerza progresista del país que al 15 de septiembre de 2010 había logrado en 5 meses recolectar más de 1,342,876 firmas de personas mayores de 18 años para la auto convocatoria a una Asamblea Nacional Constituyente, es decir casi el 30\% del padrón electoral estimado en cerca de 4.6 millones de votantes, de los cuales casi un millón se hallan en el exterior.

El Frente Nacional de Resistencia a raíz del Golpe de Estado, no obstante la importante fuerza social que representa, ha debido enfrentar un escenario de difamación mediática, calificativos de inteligencia militar como grupo con potencial insurgente, persecución judicial y política y en general su membrecía es la principal víctima de las violaciones a derechos humanos que se cometen en el país, en un escenario de agudización de la inseguridad ciudadana a tal punto que el país alcanza la alarmante tasa de 66.8 homicidios por 100,000 habitantes, una de las más altas del continente, lo que facilita la fachada para desresponsabilizar al Estado por los crímenes contra periodistas, dirigentes campesinos, sindicales, magisteriales, defensores de derechos humanos, activistas del Frente de Resistencia lo que aumenta las posibilidades de consolidar la impunidad de las violaciones a derechos humanos.

\section{ESTADO DE LAS VIOLACIONES A DERECHOS HUMANOS EN HONDURAS7}

\subsection{Violaciones relacionadas a la defensa del Derecho a la tierra, medio ambiente y otros recursos naturales.}

\footnotetext{
${ }^{7}$ NOTA del professor Scott: Por razones de espacio (traducción de este documento se limita a 10 páginas), estoy omitiendo las secciones extensas sobre las ejecuciones extrajudiciales, la tortura,las detenciones ilegales y arbitrarias, las amenazas a la seguridad de la persona, y violaciones de la libertad de expresión y de los medios de comunicación. Estos están bien documentadas por múltiples fuentes (y por tanto disponibles por separado a la Comisión Permanente), mientras que la situación que se describe abajo (en la sección que he conservado) no es tan bien conocida.
} 
Desde inicios de los años 90so con la aplicación de las medidas de ajuste estructural a la economía y de expansión del modelo neoliberal a través de la globalización se inicio en Honduras inicio un proceso de contrarreformas agrarias, de otorgamiento de concesiones a los recursos naturales incluso en áreas protegidas y en territorios de pueblos autóctonos y afro descendientes.

La expansión de esos proyectos de neo colonización fue facilitada por reformas legales, incluyendo al texto Constitucional para apropiarse de territorios sujetos a tutela de derechos colectivos y de los pueblos.

Algunas de estas apropiaciones han activado tensiones graves como es el caso de la zona conocida como El Bajo Aguán donde desde principios de la década de los 90 se inició el proceso de compra venta de latifundios amparados en la Ley de Modernización y Desarrollo del Sector Agrícola, que concluyó con la venta de los activos de 40 empresas campesinas al poderoso empresario Miguel Facussé, y a otros como René Morales, Reinaldo Canales y otros terratenientes de menor poder económico y político de la región. Por la violación a los procedimientos en la venta de tierras establecidas en la Ley de Reforma Agraria, estas transacciones siguen siendo objeto de investigación (FIAN, mayo 2010: pág. 3).

El informe de FIAN Honduras señala que desde el año 2001 un número de 28 cooperativas campesinas se organizaron en el Movimiento Campesino Unificado MUCA para la reivindicación del derecho a la tierra. Durante el gobierno de Manuel Zelaya se conformó una comisión tripartita entre campesinos, terratenientes y gobierno con el propósito de solucionar el conflicto. Los terratenientes se comprometieron a revisar la legalidad en la propiedad de la tierra e incluso a que se remidieran los terrenos que ocupan, 18 independientemente de los resultados que se obtuvieran de las investigaciones sobre la legalidad de la compra venta de esas tierras (FIAN, mayo 2010).

Este proceso se interrumpió por el golpe de Estado reactivando tensiones que han costado la vida de 11 campesinos en lo que va del 2010 y de 3 guardias de seguridad. El Gobierno de Porfirio Lobo Sosa firmó un acuerdo en abril de 2010 con 24 organizaciones de MUCA en un clima de alta militarización de los territorios ocupados por los grupos campesinos. A la fecha el acuerdo ha resultado incumplido pues no se han entregado la totalidad de las tierras pactadas y están vigentes 152 ordenes de captura contra los campesinos por la posesión de tierras que paradójicamente forman parte del acuerdo político con el Estado.

En la zona se ha denunciado operan igualmente grupos irregulares y guardias de seguridad privada de los terratenientes que han realizado ataques a los campesinos con los saldos de muertes apuntadas, además de que se denuncia la presencia de posibles paramilitares colombianos contratados por los empresarios Facusse, Morales y Canales. Del lado de la oligarquía de la zona se acusa a los grupos campesinos de ser un movimiento guerrillero asesorado por organizaciones terroristas internacionales, en tanto la Plataforma de Derechos Humanos constata en sus diversos comunicados la extrema pobreza en que vive la población campesina de la región del Aguán. 


\section{PATRONES MAS COMUNES EN LAS VIOLACIONES A DDHH}

En materia de derechos humanos denominamos patrones al conjunto de hechos y circunstancias que de manera repetida se cometen indicando los rasgos esenciales del modus operandi de la ejecución de las violaciones a derechos humanos, el perfil de víctimas o agresores, las categorías de derechos violadas, entre otras circunstancias que se vuelven típicas. Aunque también hechos que parecieran ser aislados pueden revelar patrones en referencia a eventos conocidos en otros contextos y que reflejan que se trata de una réplica.

En general los principales patrones que caracterizan las violaciones a los derechos humanos en Honduras son las siguientes:

- Mayoritariamente el perfil de las víctimas son defensores y defensoras de Derechos Humanos activistas de derechos de la mujer, LGTBI, ambientalistas, sindicalistas, campesinos organizados, periodistas, activistas del Frente Nacional de Resistencia, o sus familiares; litigantes o defensores del Frente de Abogados en Resistencia, dirigentes sociales de ongs, estudiantes organizados, empresas de comunicación social (radios, televisoras, prensa, incluyendo medios de comunicación social alternativa y comunitarios); entre otros. $\ldots$

- Represión como método: Existe en varios tipos de violaciones la participación directa y constatable de agentes del estado como ser en ataques con resultado muertes durante manifestaciones, uso abusivo de la fuerza incluyendo utilización de armas letales e instrumentos que causan dolor y tortura.

- En las violaciones a los derechos sociales la responsabilidad directa estatal es constatable tanto por acción (concesionamientos, aprobación de leyes, emisión de resoluciones administrativas o judiciales) como por omisión, tolerancia o aquiescencia hacia grupos de poder político y económico y otros facticos.

- En varias de las diferentes tipos de violaciones se observan patrones de vigilancia, hostigamiento, amenazas, llamadas anónimas, mensajitos amenazantes, allanamientos fingiendo robos en casas o centros de trabajo. Algunas de las amenazas reflejan odio contra la posición política de la persona, o discriminación de género, orientación sexual, posición económica.

- Utilización de lugares clandestinos de detención. Se señala también la existencia solo en la capital, Distrito Central, operan cuatro centros de operaciones clandestinas, donde las víctimas son vejadas interrogadas y luego abandonadas en alguna calle poco transitada (COFADEH, 2010: 30).

- El otorgamiento de medidas cautelares no es una medida que garantice una mayor protección y tutela ante ataques a la vida o amenazas a muerte que persisten aún después de que el Estado es notificado de su deber de proteger a la persona.

- Se detecta en los casos que la responsabilidad por violaciones a derechos humanos es visible, que todos los cuerpos armados del país están involucrados en las mismas (Fuerzas Armadas con todas sus ramas, Policía Nacional y todas sus Direcciones, Policía Municipal de las ciudades principales del país, guardias de empresas de seguridad privada). Lo anterior expresa el carácter represivo de los funcionarios. 
- En los casos de atacantes anónimos las organizaciones de derechos humanos señalan haber detectado un perfil de agresores que podrían pertenecer a cuerpos clandestinos o poderes paralelos pues se detecta entrenamiento especial como ser seguimiento, manejo especial de armamento, tipo de arma utilizada, forma de ataque, contextura física de los agresores y algunos sobrevivientes refieren reconocer la jerga militar en las conversaciones y haber detectado el acento de personas extranjeras particularmente de sur América (COFADEH, 2010). Estos aparatos o cuerpos clandestinos podrían ser la herencia de estructuras clandestinas del Estado impunes (ejemplo el Batallón 3-16 que fue creado por el fallecido General Álvarez Martínez y que funcionó durante la represión de los años 80s). Aunque esos cuerpos paralelos pareciera fueron desmontados, su membrecía nunca fue depurada de las instancias policiales y militares, y hoy día muchos alcanzaron los altos mandos de esas instituciones. Todo lo anterior apunta a que se ha instado la conformación de nuevos aparatos o cuerpos clandestinos que estarían operando coordinados o alineados con agentes de estructuras oficiales especiales - se ha detectado participación en algunos ataques, amenazas e infiltraciones a agentes del Comando Especial Cobras, Guardia de Honor Presidencial, Grupo Especial Antisecuestros, Unidad de Análisis Policía Preventiva, Batallón de Comunicaciones, etc. La Comisión Interamericana ha constatado la existencia de estos grupos ...(CIDH, junio 2010: pág. 31).

- En las ejecuciones extrajudiciales se observa la utilización de sicarios con pasamontañas o no. También se han utilizado pandilleros contratados para cometer los ataques.

- Muchos ataques son en la vía pública, en la vivienda de la víctima o su centro de trabajo, desde vehículos en marcha, algunos de lujo, y motocicletas.

- Algunas de las víctimas fueron interceptadas y detenidas/desaparecidas por algunos días hasta que sus cuerpos fueron encontrados.

- Algunas víctimas habían sido detenidas administrativamente por la policía en los días previos o en los meses cercanos.

- El estado de los cuerpos refleja saña, tortura, retención temporal (posiblemente para interrogatorio) y ejecución extrajudicial de varios disparos de armas de grueso calibre principalmente en la cabeza-, el cuerpo aparece a veces atado de pies y manos y suele ser abandonado en las periferias de las comunidades -fincas, matorrales, carreteras-.

\section{FACTORES QUE CONTRIBUYEN A LA IMPUNIDAD EN DDHH ... 5.1 FACTORES DE IMPUNIDAD EN HONDURAS}

\section{a) Factores Normativos:}

... La Alta Comisionada de las Naciones Unidas para los Derechos Humanos en su informe de marzo de 2010 sobre las violaciones de los derechos humanos en Honduras desde el golpe de Estado de 28 de junio de 2009, recomendó - revisar o derogar la legislación nacional incompatible con las normas internacionales, en particular las disposiciones relativas a los delitos de sedición y manifestación ilícita, la libertad de expresión, los derechos politicos y electorales, la tortura, la independencia del poder judicial, la Ley de policia y convivencia Social, y la Ley de estado de sitio".

Otras disposiciones que facilitan la violación de derechos humanos son las reformas al Código Procesal Penal para expandir el uso de la prisión preventiva y limitar la aplicación de medidas 
desjudicializadoras, la propuesta de los operadores de justicia para la reducción a 16 años la edad de ingreso de un menor a una cárcel de adultos; la vigencia de legislación que estimula la detención por —sospechas\| como el tipo penal de asociación ilícita, la Ley de Policia y Convivencia Social que autoriza la detención administrativa por mera sospecha o la detención de personas por - vaganciall de aplicación directa a jóvenes estudiantes, población LGTBI, trabajadoras comerciales del sexo o por vestimenta o apariencia. Particular referencia merece la normativa que favorece la criminalización de la protesta social a través de figuras como el delito de sedición, terrorismo y manifestación ilícita.

Adicionalmente se agrega la falta de tipificación del delito de desaparición forzada o una mejor y más precisa definición de los delitos de tortura, explotación sexual y el de discriminación (Informe organizaciones no gubernamentales de Honduras al EPU: 2010).

\section{a.1) El caso particular del Decreto de Amnistía.}

Un caso especial de impunidad normativa en Honduras es la aprobación de un Decreto de Amnistía (2-2010) por el Congreso Nacional del régimen de facto el 26 de enero de 2010 y sancionado por el Presidente Porfirio Lobo el mismo día de su ascenso al poder el 27 de enero de 2010; mismo que fue publicado rápidamente en La Gaceta Oficial el 2 de febrero de 2010 y entró en vigencia el 22 de febrero.

Dicho decreto fue propuesto originariamente en el proyecto del Acuerdo Tegucigalpa-San José para la restitución del presidente Zelaya en agosto de 2009 por el Presidente de Costa Rica, Oscar Arias. La existencia de una amnistía fue rechazada por el régimen de facto y el propio presidente Manuel Zelaya por lo que no aparece como parte del texto definitivo denominado Acuerdo Guaimuras...

Pese a que la amnistía dejo de ser parte del acuerdo fracasado, los diputados que siguieron ejerciendo sus funciones durante el régimen de facto aprobaron un decreto de amnistía que incluyó delitos como Traición a la Patria, Delitos contra la forma de Gobierno, Cambio en la forma de Gobierno mediando fuerza o fuera de las vías legales;...

El texto del decreto señala que el mismo no aplica a violaciones a derechos bumanos, ni a delitos de corrupción. Aunque los considerandos del decreto establecían que su misión era reconciliar a la familia hondureña y favorecer las violaciones a la ley imputadas a Manuel Zelaya por sus supuestas intenciones continuistas al pretender convocar a una Constituyente19, lo cierto es que los más beneficiados del mismo son los mismos diputados que el 28 de junio del 2009 emitieron un decreto contra Constitución separando sin facultades para ello al Presidente Zelaya que fue secuestrado por las Fuerzas Armadas y nombrando en su lugar a Roberto Micheletti, presidente del Congreso Nacional en ése momento.

En declaraciones posteriores el Presidente derrocado Manuel Zelaya ha manifestado no tener interés de acogerse a ese decreto de amnistía pues sus actuaciones de convocar a una consulta para preguntar a la población sobre si deseaba una Constituyente, no eran ilegales y que los juicios en su 
contra eran nulos por haber sido iniciados después del Golpe de Estado, cuando el país fue sometido a una dictadura.

... La práctica de aplicación de éste decreto ha significado dejar impunes a las más altas autoridades civiles y militares partícipes del Golpe de Estado, además de los grupos facticos civiles que participaron de dicha conspiración.

En los mismos casos de violaciones a derechos humanos como ser los delitos contra los medios de comunicación que a falta de una figura penal expresa han sido enjuiciados por abuso de autoridad, la misma Fiscalía ha solicitado su sobreseimiento por estar amnistiados. Las detenciones arbitrarias, el trato cruel e inhumano y la prohibición de extradición o expatriación de personas contempladas en los tratados internacionales de derechos humanos, fueron sujetos de éste manoseo de la legislación al ser amnistiados e interpretadas estas violaciones como meros actos de abuso de autoridad sujetos de amnistía.

Por el lado de los presos políticos o perseguidos por el Estado por manifestarse contra el golpe, han sido humillados por los jueces al aplicárseles la amnistía que los califica como terroristas, sediciosos o rebeldes (delitos políticos). Esta anomalía normativa imposibilita la reivindicación de los derechos de los presos políticos, particularmente el derecho a ser considerados inocentes, a un juicio justo (particularmente reivindicar su nombre), a la participación en manifestaciones, libertad de opinión, el derecho a la resistencia e insurrección contra golpes de Estado que prevé la Constitución hondureña en su artículo número tercero....

\section{b) Factores Político -Institucionales de la impunidad en Honduras b.1 La falta de Independencia del sistema Judicial y de los mecanismos oficiales de protección de derechos humanos.}

En general históricamente el sistema de justicia hondureño suele ser calificado por las encuestas de opinión ciudadana como corrupto y politizado...

Según el informe de Observaciones Preliminares de la CIDH sobre su visita a Honduras del 15 al 18 de mayo: - se constató durante la visita de mayo de 2010, que las violaciones a los derechos humanos han continuado así como la impunidad. De acuerdo a lo observado, esta situación se debería a varios factores. Las autoridades encargadas de investigar, juzgary sancionar continúan negando en forma sistemática la existencia de las violaciones a los derechos humanos cometidas, lo que se traduce en inactividad, tolerancia e incluso sobreseimiento de quienes ejecutaron el golpe de Estado y las violaciones indicadas... Por otra parte, la Comisión observó que en este contexto de impunidad no existe un procedimiento destinado a garantizar un proceso público y trasparente para la selección y elección de candidatos para los altos cargos del sistema de administración de justicia. Aunque algunos funcionarios del sistema de justicia tengan la intención de investigar en forma debida, ellos no cuentan con los medios necesarios porque la Policía Nacional, encargada de la investigación criminal, no tiene la capacidad ni la preparación requerida, además de estar señalada de tener en sus filas altos niveles de corrupción (CIDH: junio 2010, pag.22 y 23). 


\section{b.2 Actores del sistema de Justicia y su rol en la impunidad en Honduras.}

b.2.1 El Comisionado Nacional de los Derechos Humanos (CONADEH), que es la institución de rango Constitucional creada para garantizar los derechos y libertades reconocidos en esta Constitución, y también de los Tratados, Pactos, Convenciones y sus Protocolos Facultativos ratificados por el Estado hondureño. ... El titular del Comisionado fue reelecto en el 2009 para un periodo de 6 años, finalizando su mandato en el año 2015.

... [L]a situación de indefensión en el país se consolidó cuando el titular del Comisionado de Derechos Humanos, Ramón Custodio, negó que haya existido una ruptura del orden Constitucional, defendió la -legalidad|| de los decretos de estados de excepción y los toques de queda del régimen de facto, justificó la clausura de medios - porque alentaban la sedición y era preciso mantener el orden públicoll, y rechazó la existencia de violaciones a derechos humanos, por lo tanto las pocas denuncias que ciudadanos pudiesen haber interpuesto en el organismo, no fueron debidamente procesadas....

$\mathrm{Al}$ respecto la CIDH en su informe del 30 de diciembre 2009 expresa: "la Comisión tomó conocimiento del grave papel desempeñado por el Comisionado Nacional de Derechos Humanos, Ramón Custodio López, quien al negar la existencia del golpe de Estado, impidió que los habitantes de Honduras pudieran contar con un mecanismo independiente de protección a los derechos humanos".

El Comisionado Nacional de derechos Humanos ha calificado los comunicados e Informes de la CIDH como manipulados y cuyo objetivo es dañar a Honduras, con el propósito de ahuyentar la inversión extranjera....

\section{b.2.2 Los órganos de control interno de la Policía Nacional.}

... Durante el golpe de Estado los ejecutores materiales de las violaciones evidentes a los derechos humanos fueron mayoritariamente las Fuerzas Armadas y la Policía Nacional, con todas sus ramas o dependencias que se implicaron sin excepción. Los órganos de control tanto en la Policía Nacional, como en las Fuerzas Armadas de Honduras (Insectoría General, Auditoría Interna e incluso existe una Dirección de Derechos Humanos y Derecho Humanitario), omitieron cumplir con sus funciones e incluso participaron activamente en la planificación de las acciones violatorias, pues el régimen de facto llamó a todas las unidades policiales y militares a -actuar en defensa del orden democrátic....

\section{b.2.3 E1 Ministerio Público, con especial referencia a la Fiscalía Especial de DDHH}

El Ministerio Público es la institución de rango Constitucional que tiene bajo su cargo ejercer en representación de la víctima la acción pean pública. La Fiscalía como suele llamársele goza de la atribución del monopolio exclusivo de la acción penal pública es decir en los delitos de orden 
público sólo él tiene la llave para abrir el enjuiciamiento penal, por lo que su independencia y eficacia en la investigación es fundamental para la lucha contra la impunidad....

En el caso de la Fiscalía de la República en el más alto nivel sus titulares han sido señalados de corresponsabilidad directa en el Golpe de Estado y de haber falsificado enjuiciamientos ex post para legitimar el secuestro militar y expatriación del presidente Manuel Zelaya....

El rol de la fiscalía no solo fue lavando el golpe sino también se valió de su monopolio penal para lanzar toda su maquinaria institucional para perseguir a la emergente resistencia al golpe de Estado, llegándose a contabilizar más de 200 juicios a lo largo del país (algunos casos implicaron acusaciones colectivas como la de los 57 campesinos que mantuvieron la toma del Instituto Nacional Agrario), acusaciones contra funcionarios del Poder Ejecutivo de Manuel Zelaya garantizando su exilio y no retorno en caso de restauración constitucional; acusaciones contra alcaldes en resistencia, dirigentes magisteriales (el número mayormente acusado), y manifestantes del movimiento surgido a raíz del golpe el Frente Nacional de Resistencia. Las acusaciones incluyeron desde corrupción -contra alcaldías leales a Zelaya y sus ministros-, lavado de dinero y recibir fondos de Venezuela y de las FARC de Colombia (a los dirigentes del Frente), de terrorismo, sedición, daños, manifestación ilícita. Esas acusaciones tuvieron la característica de ser rápidamente ventiladas, libradas ordenes de captura, encarceladas y pese a la amnistía en algunos casos las personas aún se defienden de los mismos.

No sucedió lo mismo en el caso de las violaciones a derechos humanos, pues la Fiscalía Especial [de Derechos Humanos] se caracterizó por ser lenta y tolerante pues además de su inacción en acusar a los máximos responsables de los crímenes no ejerció de oficio el control externo sobre los ilegales Decretos que establecieron el Estado de Excepción y los toques de queda, no actuó para decomisar armas de uso prohibido contra manifestantes por parte de la policía y el ejército como el gas picante, tubos de metal, bates de beisbol, palos con nudos, cadenas y otras armas no reglamentadas por los estándares internacionales para esos efectos.

Como ejemplos el CPTRT presentó 35 denuncias por tortura y malos tratos ante la Fiscalía de Derechos Humanos, en tanto el Frente de Abogados en Resistencia reportó 46 denuncias por similares hechos. Cofadeh manifiesta haber llevado a la Fiscalía de Derechos Humanos la casi totalidad de sus casos; sin embargo pasado más de un año y medio apenas una decena de casos han sido presentados y la mayoría por delitos de pena menor como el abuso de autoridad o la violación de los deberes de los funcionarios que están tipificados como en perjuicio de la administración pública y no de la víctima (interpretación que desvalora la gravedad de las violaciones a derechos humanos) y facilita a aplicación de la amnistía a las violaciones a derechos humanos.

... Los titulares del Ministerio Público fueron electos en el año 2009 para un periodo de 5 años, finalizando su mandato en el 2014. 


\section{b.2.4 E1 Poder Judicial.}

... Durante el golpe de Estado el Poder Judicial hondureño generó condiciones previas favorecedoras como la emisión de resoluciones judiciales para frenar la encuesta a la población sobre la Constituyente; cuatro días antes del Golpe el pleno de magistrados en un tiempo record ordenó la restitución a su cargo del jefe de las Fuerzas Armadas Romeo Vásquez Velásquez (separado por el presidente Zelaya por ser funcionario de su libre nombramiento según sus facultades Constitucionales). Las Fuerzas Armadas con el general Vásquez a la cabeza materializó el ataque armado a la residencia del presidente Zelaya, su secuestro en horas de la madrugada y su extrañamiento del país en un avión de la Fuerza Aérea. ...

Al igual que la Fiscalía General, los máximos titulares de la Corte Suprema de Justicia son responsables del blanqueo del Golpe de Estado al expedir con posterioridad al golpe documentación falsa como la orden de captura presentada a la prensa 3 días después del golpe (pero no al mandatario la madrugada de su captura). El máximo tribunal se adhirió a la tesis de que en Honduras existió - sucesión constitucional, apoyo a Roberto Micheletti en su dictadura de varios meses al emitir comunicados convocando a su personal a participar de las manifestaciones públicas planificadas por los golpistas.

También la Corte Suprema de Justicia y jueces y magistrados inferiores subordinados han impedido la investigación, el juzgamiento y la sanción de los delitos por la ruptura democrática y las violaciones a derechos humano. Para el caso en las pocas causas iniciadas por derechos humanos (12) los jueces de instancias inferiores se han apurado a dictar cierres definitivos de los procesos. En tanto se mantiene abiertas causas contra campesinos, dirigentes sindicales, funcionarios del gobierno derrocado, incluyendo al propio ex presidente Zelaya quien vive en el exilio.

Según la CIDH la impunidad generalizada por violaciones a los derechos humanos se encuentra facilitada por decisiones de la Corte Suprema de Justicia que debilitan el estado de Derecho... En este sentido, la Comisión observa que se han dictado sobreseimientos definitivos a favor de personas que propiciaron el golpe de Estado o que durante su desarrollo cometieron ilícitos... Además del cuestionado rol de la Corte Suprema de Justicia durante el golpe de Estado, con posterioridad ha decidido, por un lado, sobreseer a los militares acusados de participar en el golpe y por otro, despedir a jueces y magistrados que buscaron evitarlo por vías democráticas (CIDH. Junio 2010, par. 95). \{La nota 24: El 26 de enero de 2010, horas antes de la toma de posesión del nuevo presidente hondureño, Porfirio Lobo, el juez especial y Presidente de la Corte Suprema de Justicia, Jorge Rivera, sobreseyó a los acusados.\}

Para las organizaciones de derechos humanos la situación de violaciones a la independencia también es bastante grave particularmente por la manipulación y la arbitrariedad en el nombramiento, traslado y remoción de jueces y magistrados. El acto más grave fue la destitución de tres jueces, una magistrada y un defensor público afiliados a la Asociación de Jueces por la Democracia por haber emitido opiniones, incluso de corte académicas contra el golpe de Estado....

También recursos especiales de tutela de los derechos humanos contenidos en la Constitución y en la Ley de Garantías Constitucionales como el Hábeas Corpus, Inconstitucionalidad y el Amparo han 
resultado ineficaces ante la Sala de lo Constitucional de la Corte Suprema de Justicia. En general se denuncia la resolución tardía de los mismos y la emisión de resoluciones que trasladan la competencia de proteger derechos a procedimientos más largos del juicio administrativo. Según un informe elaborado por CIPRODEH desde el 28 de junio al mes de octubre del año 2009 se habían presentado 87 recursos de amparo contra diversas actuaciones los cuales se hallan en etapa de -estudio.

Los magistrados de la Corte Suprema de Justicia son 15 y fueron electos en el año 2009 para un periodo de 7 años, finalizando su mandato en el 2016. Los magistrados de éste alto tribunal tienen prohibición de ingreso a Estados Unidos y varios países de la Unión Europea.

\section{FACTORES SOCIALES}

... c.1 Poderes fácticos en Honduras. El termino Poder factico es definido por la Real Academia Española como un sector de la sociedad al margen de las instituciones políticas que ejerce sobre aquella una gran influencia, basada en su capacidad de presión, por ejemplo, la banca, la empresa privada, la Iglesia, los militares, los medios de comunicación, el narcotráfico, etc.".

... Los grupos fácticos en Honduras no solo están integrados por el sector empresarial, industrial y bancario; también se conforma por los denominados - mandaderos o grupos que reciben su influencia y finalmente negocian canonjías y protección como son los sectores militar (que han incursionado desde hace más de dos décadas en las grandes empresas, incluyendo la banca), las cúpulas de las iglesias, y las elites de los partidos políticos con quienes pactan los modos y formas de obtener poder y ganancias del Estado y la sociedad....

Desde el ascenso al Poder de Manuel Zelaya en el año 2006 estos grupos como lo habían hecho siempre reclamaron su cuota de poder, a lo que después de varios enfrentamientos el derrocado presidente declaró públicamente que él no mandaba en Honduras y que las grandes corporaciones mediáticas lo coaccionaban abusando de la libertad de expresión para chantajear y mantener capturado al Estado.

Desde inicio de su mandato el gobierno de Zelaya soportó enfrentamientos con algunos de los grupos más poderosos del país particularmente cuando el gobierno tomó autonomía en la compra y la importación de combustibles, se distanció de los oligopolios que detentaban las concesiones de los servicios públicos de telecomunicaciones, energía eléctrica, construcción e incluso opto por crear un canal de televisión oficial para el Estado y aprobar un incremento de más del 62\% al salario mínimo frente al 8\% que ofrecían los empresarios.

Los grupos facticos serían los ideólogos del Golpe de Estado de junio de 2009, como un mecanismo de la subsistencia de su poder político histórico, para ello cooptaron a través del Congreso Nacional el nombramiento de las autoridades máximas del Poder Judicial, Fiscalía, Tribunal Superior de Cuentas y CONADEH; todos electos a inicios del año 2009 mediante su influencia visible - la empresa privada para el caso integró la junta nominadora de elección de magistrados- o a través de la influencia subterránea. ... 
A inicios del 2009 y frente al proyecto de la Consulta pro constituyente los grupos fácticos se ven obligados a apariciones públicas que no es su forma tradicional de actuación por lo que deciden organizar previo al Golpe de Estado (y mantienen el financiamiento todavía) de varias asociaciones entre las que sobresalen la Unión Cívica Democrática (UCD), el Grupo Paz y Democracia, y el grupo estudiantil, Generación X el Cambio, todos encargados de realizar el trabajo sucio de desestabilización del gobierno de turno, lo hicieron con Zelaya hasta derrocarlo y lo están haciendo con campañas mediáticas hacia Porfirio Lobo quien ha denunciado intentonas de derrocamiento por parte de éstos grupos.

... En suma los poderes fácticos en Honduras son quienes detentan el Poder real en el Estado y sus instituciones. Su capacidad de influencia es tal que en la historia de Honduras nunca una persona o corporación ligada directamente a estos grupos ha enfrentado la justicia. Viven una impunidad selectiva, que les garantiza una ausencia total de castigo como sector de poder real y altamente peligroso en términos de potenciales alianzas con el financiamiento y protección que puedan obtener del crimen organizado.

\section{c.2 La Militarización}

... En Honduras la Doctrina de la Seguridad Nacional implementada durante el conflicto de la guerra fría fue el marco teórico de las relaciones de poder militares y en donde el Poder civil y sus instituciones se someten voluntariamente y complacientemente a su fuerza y valores con el consecuente debilitamiento de la institucionalidad estatal y por ende del Estado democrático de Derecho.

Los procesos de paz en Centroamérica y la firma del Tratado Marco de Seguridad Democrática del año 1995 supusieron un paulatino retroceso de los militares en su posición de jerarquía en el poder civil, de reducción de su presupuesto fiscal en los primeros años de la firma de dichos acuerdos, de retiro de posiciones estratégicas en el Estado, aunque ello no significaron un abandono de su posición social y económica privilegiada en su rol como poderosos empresarios de la banca nacional, la industria cementera, la seguridad privada, o la venta de armas donde mantienen un mercado cautivo y monopólico siendo los mayores beneficiados de la ola creciente de violencia en el país.

Justamente es el tema de la inseguridad ciudadana el que "justificó" la reaparición de los militares hondureños en el escenario social y político del país. Ante un poder civil débil y temeroso de la avanzada del crimen organizado se llamó a los militares para que reaparecieran en los escenarios del patrullaje en calles, asesoría en inteligencia, apoyo a labores de investigación criminal y control del espacio marítimo, aéreo y terrestre, tareas que deben ser ejecutadas por las Fuerzas civiles del país.... El propio presidente Zelaya favoreció la re militarización en Honduras y fue su estrategia ante las presiones de los grupos facticos, buscar el favor del poder militar a los que benefició con la reelección de su comandante Romeo Vásquez Velásquez quien había alcanzado la fecha de retiro que manda su propia Ley Orgánica; les asigno tareas en funciones de "protección" del bosque y los 
recursos naturales lo que les abrió la incursión en un nuevo rubro de corrupción y les llamó para apoyarle en la administración de la empresa estatal de energía eléctrica, ENEE....

A nivel nacional desde [el] día [28 de junio de 2009] las Fuerzas Armadas tomaron control importantes dependencias públicas consideradas estratégicas y que desde esa fecha pasaron a control de las Fuerzas Armadas, incluyendo la supeditación de la Policía Nacional al ejército. Las instituciones civiles controladas por la militarización son la Empresa Hondureña de Telecomunicaciones HONDUTEL que suministra los servicios estatales de telefonía, la Dirección de Migración y Extranjería, la Marina Mercante Nacional, la Dirección de Aeronáutica Civil, además de posiciones de poder en la Empresa Hondureña de Energía Eléctrica, la Comisión Permanente de Contingencias COPECO y apertura de oficinas en la Secretaría de Seguridad y en el Congreso Nacional de la República. \{La note 27: El general Romeo Vásquez Velásquez ha sido nombrado como Gerente de la empresa nacional de telecomunicaciones (HONDUTEL)... \} La presencia en el Poder Ejecutivo que ha existido siempre bajo el nombre de Guardia de Honor Presidencial se aumentó y ha pasado a ser una oficina de inteligencia civil como se ha detectado a varios de sus integrantes infiltrados en las manifestaciones y asambleas del movimiento sindical, popular y Frente Nacional de Resistencia.

Esta modalidad de administración militar de instituciones civiles fue común durante los años 70 y 80s en plena vigencia de la guerra fría y facilita consolidar el denominado stablishment militar en la vida civil y el poder político de la nación hondureña.

... El 14 de mayo de 2010 el Congreso Nacional aprobó un Decreto a través del cual se instruye a la Secretaría de Defensa Nacional a cooperar con "el personal y medios estrictamente necesarios de la Fuerzas Armadas y de acuerdo a la evolución de cada situación, a efecto de que la Policía Nacional cumpla de manera eficiente y oportuna las funciones para el restablecimiento de la paz, la prevención, control y combate del delito.” A cargo de ése decreto se facilito la militarización de la zona del Bajo Aguan donde tres batallones de otras regiones del país se trasladaron para la intimidación al movimiento campesino bajo el argumento que un movimiento insurgente se gesta en la zona.

Así configurada la militarización es un factor fundamental de la impunidad en Honduras, constituyen un grupo real de poder que controla por sumisión o por miedo al poder civil, incluyendo jueces y magistrados que no son capaces de enjuiciarlos. La militarización favorece las violaciones a derechos humanos en dos niveles: el primero de ellos, como perpetradores directos de las mismas; y en segundo lugar como poder real en la configuración del orden político e institucional del país. 


\section{Appendix 5 - Extracts from 2011 COFADEH Report}

The next approximately 30 pages (pp 48 - 79) consists of the extracts prepared by Bertha Oliva from the Spanish-language report, COFADEH, Informe - Situación de Derechos Humanos en Honduras (Enero 2010 a Enero 2011) (COFADEH, 2011), and tabled with the Standing Committee on Foreign Affairs and International Development in advance of the March 9, 2011, hearing. It appears on the following pages in two versions, firstly the English translation by the Parliament of Canada and secondly the original Spanish. The French translation prepared by the Parliament of Canada will be published online at:

http://www2.parl.gc.ca/CommitteeBusiness/StudyActivityHome.aspx?Cmte=FAAE\&Language= E\&Mode $=1 \& \operatorname{Parl}=40 \& S e s=3 \& S t a c=3806929$.

The versions thus appear in the following order:

- COFADEH, Report on the Human Right Situation in Honduras (January 2010 to January 2011) (COFADEH, March 2011)

$$
\text { pp 48-63 }
$$

- COFADEH, Informe - Situación de Derechos Humanos en Honduras (Enero 2010 a Enero 2011) (COFADEH, marzo 2011)

$$
\text { Pp } 64-79
$$




\title{
Human Rights Situation in Honduras
}

adapted from Chapter 1 of the

\section{Report on the Situation of Human Rights in Honduras:}

January 2010 to January 2011 (March 2011)

\author{
by the
}

Committee of Relatives of the Detained/Disappeared in Honduras - COFADEH

The general human rights situation in Honduras remained critical in 2010 due to the politicoinstitutional weaknesses resulting from the military coup. In particular rights were systematically violated, such as the rights to life, political participation and dissent, freedom of expression and information, justice and equality, land tenure and food.

The activities of hit-men in police- or military-type covert operations, the financial and political empowerment of state security forces and the territorial and cultural advancement of organized crime continued to have a serious impact on human rights.

Although the official position is to strongly denounce the activities of drug trafficking and organized crime, in practice state officials fight resistance activities against the military coup and the efforts to strengthen the Frente Nacional de Resistencia (National Popular Resistance Front, FNRP), particularly targeting young people.

The recent phenomenon of paramilitarism ${ }^{8}$ has grown through independent action on the ground in areas such as the Aguán river banks and the valleys of Santa Barbará (Quimistán, Azacualpa, Macuelizo, Sula and others), giving rise to multiple crimes and spreading unrest and terror. Covert groups work against human rights defenders and civil society groups, including women's advocates, trade unionists, journalists and NGOs, who have faced attacks against their offices and their own lives.

Furthermore, along the same strategic lines, security and defence officials have instigated a menacing public discourse, maliciously and falsely equating the effort of protecting and promoting

\footnotetext{
8 Alfredo Jalife, Mexican geo-political scientist defines the paramilitary element as a creation of totalitarian regimes at war. He explains that this way, "the State disguises its worst intentions," which it carries out through this paramilitary groups, essentially consisting of former militia, former criminals or people who specifically serve these perverse interests.
} 
human right with the activities of terrorist organizations, ${ }^{9}$ endangering the safety of rights advocates.

Of particular concern was the theft by unknown perpetrators of information related to the torture of a lawyer from Codafeh. In some cases, the information illegally obtained by the public security forces was used by some prosecutors to initiate legal proceedings against human rights defenders and social activists. ${ }^{10}$

Although the Inter-American Commission on Human Rights, who visited Honduras in May 2010, demanded assurances from the State that human rights defenders would receive adequate support and protection, their situation remained precarious.

The LGTB community, including its leadership, has been the target of persecution and hate crimes. The community reported 25 murders in 2010, while indigenous and Garífunas organizations reported death threats and systematic attacks against their ancestral heritage sites and offices.

Impunity remains the most important feature of virtually all these events, demonstrating the dysfunction of the State's legal institutions and the serious risks posed to the victims, their families and their organizations. Given this background of violence, lack of safety and impunity, the risks are too high for the exercise of the rights to freedom of expression, thought and information, as well as union rights and the rights to assembly and public protest.

Also, there is nothing worse than being young and under suspicion for breaking the law, illegal association or militant resistance: young people are the main victims, according to the statistical data reporting a daily toll of over 16 dead bodies countrywide.

The repositioning of the military in the country's political sphere is occurring against this backdrop of human rights violations and is evident in the national budget, the occupation of state institutions from which it had been expelled, the display of military order on the street, the public discourse of military leaders and its hard-line, abusive and arrogant attitudes in its relationship with the public.

The military/police leadership, which participated in the coup, was one of the first sectors to benefit from a decision of the judiciary in the first few months of Lobo Sobo's regime, which put the fragile public institutions still remaining under a cloud of mistrust and suspicion.

In 18 months, militarism re-emerged as an alternative power in Honduran society, rising in parallel to the established power structure and causing human rights violations. The involvement of General

$9 \quad$ On December 14, 2010, the newspaper "El Tiempo" in San Pedro Sula, published an article stating that Security Minister Oscar Alvarez blamed human rights organizations such as the Committee of Relatives of the Detained and Disappeared in Honduras (COFADEH) for being prepared to destabilize the current government and support the armed groups in Bajo Aguán, leading prosecutors and judges to be prepared to imprison organizers. These statements also circulated in radio broadcasts.

10 Case of the defenders and journalists of Coyotito Zacate Grande, December 15, 2011. Criminalized teachers, August 20, 2010. 
Romeo Vásquez Velásquez in Hondutel, a government-owned telecommunications firm, confirms the economic, political and strategic objectives of those in uniform, from the time of the coup to this day; the same is true for Migration and the Merchant Marine.

Over the last 10 months, at least four institutions ${ }^{11}$ were militarized and two land militarization decrees were issued. The government also agreed to deploy over one thousand troops on the streets with the alleged goal of combating violence. They were joined by another 2,500 military and police personnel deployed in the north of the country, where a naval base was also opened.

As democracy reaches its breaking point, with the military assuming executive functions, exerting political pressure on the National Congress and the Supreme Court of Justice, and engaging in violence against political dissidents, we reiterate the statements made in the first half of 2010.

The facts paint a harsh picture of the democratic deficit, the loss of trust and legitimacy in public institutions, the legal formalities that ensure impunity and the backsliding on human rights in labour and economic areas.

\section{The continuation of the military coup d'état}

The second period of the coup began on January 27, 2010, after the "general election," conducted under the threat of the Army`s guns, without freedom of expression or international observers present. The most visible sign of this new phase of institutional breakdown was the dramatic increase in repression and new forms of controlling the opposition. The approach of the civilmilitary dictatorial regime is based on the impunity of the political actors of June 28, 2009, who have been placed in strategic positions in the public service, which has deepened the crisis of legitimacy of the state and governing elites.

The de facto regime's obsession with international recognition has increased targeted repression against social popular resistance leaders; the first to come under attack were the middle-level social movements, the labour movement, and peasant-farmer groups that actively opposed the package deal of the Army and Police as well as the pressure from Agribusinesses and media terrorism, which slowed the comprehensive agrarian reform that had been planned in early 2009.

The coup firmly established in the country the negative values of authoritarianism, intolerance, hard-line negotiating, failure to keep promises, and lack of respect for differences, which to date have resulted in violent means of addressing social and political unrest with radical private groups and repressive military groups, further eroding the remnants of the rule of law. This is lawlessness, aggravated by religious fundamentalism and media terrorism, which not only impose dogmas and prejudices, but also ignore, insult or discredit the social and political opposition, generating a psychological warfare mentality and even sectoral attacks, stirring up underlying social tensions.

11 August 2010, UNAH (National Autonomous University of Honduras), August 2010, INPREMAH (National Institute for the payment of Honduran teachers), November 2010, the National Agrarian Institute (INA) in Sinloa and the COPEMH (Association of secondary teachers of Honduras) facilities in Tegucigalpa. 
The breakdown of the democratic system strengthened the impunity of past decades to ultimately turn it directly into state policy, breaking the spine of the new and fragile institutions set up after the previous civil-military coup regimes. In turn, this democratic backslide is also evidenced by the corruption of justice, and mistrust arising from the inadequacy and negligence of the police and the Attorney General's office, increasingly perceived as having close ties to the coup leadership and the organized crime gangs that violate life and liberty and plunder natural resources. There is no doubt that Honduras is under a dictatorship. In this context, civil and political rights are under their worst attack from the State; something even worse is happening to the economic, social and cultural rights that are being eroded by the administrative arm of the Executive and the National Congress, which passes legislation undermining progressive policies.

The private and political sectors that led the coup and perpetuate it through the de facto regime persist in keeping alive the failed neoliberal model. Reducing the government's influence to a minimum and giving the initiative to the same business groups that control the institutions. Privatizing and licensing are the agenda. Eliminating subsidies for the poor. Giving exemptions to the groups in power and increasing the tax burden on salaried workers. Denying raises to civil servants and failing to comply with the minimum wage act, by attempting to replace the mandatory yearly increase with a bond worth less than one thousand dollars.

In the agri-sector, conflicts over land and water resources are becoming increasingly severe. People are being injured and even killed in this growing conflict. In the Aguán area, the situation is dominated by negotiation with militarization: between April and September, 11 campesinos were killed by authorities and paramilitary groups, while a land-sharing agreement between the Unified Movement of Aguán (MUCA) and Mr. Porfirio Lobo is being partly honoured. A climate of terror prevails in the area.

In addition, the tax increases passed by the National Congress in March 2010 have become a new source of conflict, as they have apparently led to dissatisfaction among business leaders themselves, and consequently among workers. The tax package known as "tax measures" and the declaration of a financial and tax emergency is aimed at taxpayers who pay sales, income and consumption taxes as well as vehicle import, air travel and progressive telephone service taxes and electricity users previously subsidized by administrative acts of decentralized agencies, who will pay rates of 200 Lempira or more.

While human rights defenders, journalists, social activists, political opponents and coup resisters are subject to persecution, international organizations (OAS, UN, EU) and their political bodies failed to restore institutional order and encouraged widespread violence and organized crime by gratuitously proposing an agreement among elites that ignores the social reality and the organized public. There is no doubt that organized crime stepped over the rubble of the rule of law and became established through front operations.

The country post the watershed of June 28, 2009, is represented in the Civic Democratic Union (Unión Cívica Democrática), which brings together the business and political leaders behind the coup and the National Popular Resistance Front (Frente Nacional de Resistencia Popular), which proposes the restoration of democratic order through the National Constituent Assembly. 
In this scenario, the dominant political class has lost control of the social forces and movements that it has handled in the past. The political equilibrium has broken down. The two-party system has self-destructed. However, the National Popular Resistance Front has emerged and swelled with farmers, unions, settlers, professionals, teachers, students, young people, women's organizations, indigenous peoples and street vendors. In response, it now faces a bloody repression that includes political persecution crimes and hate crimes.

Although the country remained under the watchful eye of international human rights organizations, Porfirio Lobo Sosa, shortly after taking office as President, signed an Amnesty Decree, as had been demanded of him since July 2009, for the exclusive benefit of the parties who thought out, organized and executed the coup d'état. ${ }^{12} \mathrm{He}$ signed this Decree halfway through his inaugural speech. Similarly, he also passed the 2010 - 2038 Plan de Nación (Plan for the Nation) and 2010 2022 Visión de País (Vision for the Country) decrees, designed to be implemented over his next seven terms in office. Essentially the continuity plan for savage neoliberalism.

This last document, which became effective on November 25, 2009, lacks consultation, legitimacy and participation, and is not intended to reduce social inequalities or foster the economic development of the population; on the contrary, it safeguards the interests of the groups in power for the long-term.

\section{Militarization and re-militarization of Honduras}

Three days after the inauguration, on January 30, he signed a security agreement with the President of Colombia, Alvaro Uribe. This agreement took effect on February 15, 2010. On that date, Oscar Arturo Alvarez Guerrero, Lobo's Minister of Security, met in Colombia ${ }^{13}$ with the Columbian Chancellor, Vice-President Francisco Santos, Felipe Muñoz, Director of the Administrative Department of Security (DAS, state intelligence), and General Óscar Naranjo, National Police Commissioner. Colombia's cooperation was apparently aimed at creating intelligence and counterintelligence units, and units to fight drug trafficking, terrorism, kidnapping, human trafficking, abuse of children involved in underage prostitution, cyber-crime and others through various institutions, including the Fiscalía de Derechos Humanos, (office of the special prosecutor for human rights), the Security and Defence ministries, the Dirección de Lucha contra el Narcotráfico (national office for combating drug trafficking) and the Judiciary.

On May 27, 2010, Porfirio Lobo signed an agreement with Peru for cooperation on production and prevention of substance abuse, rehabilitation, control of illicit trafficking in drugs and psychotropic substances and related crimes. Also, a cooperation agreement for the prevention and suppression of any money laundering activities.

On April 14, 2010, Honduras and the U.S. signed a \$4.4-million (USD) agreement to support the fight against crime by providing training and equipment for the police, in order to increase their

12 Legislative Decree 2-2010

13 Colombian Chancellor Jaime Bermúdez signed the new agreement through which the "successful" security and anti-organized-crime experience will be shared in the broader context of South-South cooperation. 
ability to combat drug trafficking, gangs, kidnappings and arms trafficking. These millions to be channelled through the Barrio Pobre project. ${ }^{14}$ This agreement was signed in Tegucigalpa's Colonia San Miguel in the presence of Security Minister Oscar Alvarez, National Police Commissioner José Luis Muñoz Licona, the Mayor of Tegucigalpa, Ricardo Alvarez, members of the police and community leaders. The organized strengthening of the intelligence and repression machines.

In July, U.S. Ambassador Hugo Llorens told reporters that public prosecutors and members of the anti-kidnapping unit of the national criminal investigation office (Dirección Nacional de Investigación Criminal, DNIC) would participate in a program of several weeks, which would help them improve professionally.

On April 13, 2010, Porfirio Lobo, together with U.S. Ambassador to Honduras Hugo Llorens, opened the new naval military base in Laguna de Caratasca, in the Gracias a Dios Department. The mission of this military unit is allegedly to bolster the war against drug trafficking in this Honduran region. The facility was built by members of the U.S. Army and U.S. Southern Command, at a cost of two million Lempiras. The base includes a multifunctional building and an operations center, which helps increase capacity to house more staff, and a new dock for anchoring the interceptor and patrol boats. ${ }^{15}$ In 2009, the United States delivered four interceptor boats in Puerto Castilla valued at US\$2.6 million.

On June 18, 2010, the Infodefensa.com Web site reported that the U.S. had decided to resume military aid to Honduras by donating 25 trucks to the army, which were delivered by Lieutenant General Ken Keen, the Military Deputy Commander of U.S. Southern Command, to Marlon Pascua, Defence Minister in the Lobo regime, and General Carlos Cuellar, Joint Chief of Staff. The donation amounts to US\$812,000. ${ }^{16}$

In July Porfirio Lobo's Secretary of Foreign Affairs told reporters that a new military base would be built in Guanaja, one of the Honduras Bay Islands in the Caribbean, for the purpose of fighting organized crime and drug trafficking as well as controlling the entire Atlantic sector.

According to official information, in addition to the U.S., Guatemala, El Salvador and Mexico also have an interest in the base. In this climate of growing militarization and reversion towards a police state, which raises the alarm in terms of social risks for entire sectors, the homes of citizens that live in the poorest areas could be illegally levelled.

The search for Truth and Justice

COFADEH came across several complaints from victims of human rights violations who reported being questioned by people with South American accents while they were held captive in covert

$14 \quad$ Honduras and the United States signed in January 2009 the agreement for this initiative, providing the country with US $\$ 3.6$ million of the US $\$ 10$ million targeted for the region, which were supplemented by an additional US $\$ 2.8$ million provided by the US in April 2010.

15 Lobo Sosa thanked U.S. President Barack Obama, "[translation] for this remarkable contribution, which represents a major step in the fight against drug trafficking and organized crime."

16 The vehicles were assigned to Special Forces units in La Venta and La BREA. 
operations centers. ${ }^{17}$ At the same time that reports of abductions and murders of trade unionists were circulating, Porfirio Lobo was entrusting Guatemalan Eduardo Stein with the coordination of the Truth and Reconciliation Commission, which was intended to investigate the events surrounding the coup of June 28, 2009.

On April 30, 2010, Decree PCM-011-2010 was published, creating the Truth Commission. ${ }^{18}$ This Commission lacks essential components for truth and justice, autonomy, independence and professionalism in human rights; at the time, national and international human rights organizations pointed out that his mandate did not include the investigation of human rights violations and that its findings had no legal consequences, and accordingly it did not contain measures to prevent repetition of those acts.

Any justice process, which in the case of Honduras can not be called transitional because we are still mired in political conflict, must meet three basic principles: 1) satisfaction of the right to know the truth; 2) the satisfaction of the right to justice; and 3) the satisfaction of the right to reparation. The official Truth and Reconciliation Commission does not comply with these principles.

Article 1 of Executive Decree 011-2010 sets out the objective of the Commission of Truth and Reconciliation as follows: "to clarify the events that occurred before and after June 28, 2009, in order to identify the factors that led to the crisis and provide the Honduran people with the information they need to ensure that these events will not be repeated."

If any doubts remained about the purview of this committee, Mr. Porfirio Lobo Sosa dispelled them when he told the media that this commission was not to judge anyone but to seek the reconciliation of the Honduran people. Lobo's statements make it very clear that the state's police/military and paramilitary machinery, which is the source of serious human rights violations will not be dismantled. Senior officials implicated in human rights violations and involved in the coup will not be removed from public administration.

And so, on May 04, 2010, the Truth Commission ${ }^{19}$ was inaugurated in the presence of José Miguel Insulza, Secretary General of the Organization of American States. ${ }^{20}$. This Commission will allegedly present its report in January 2011.

$17 \quad$ At least four covert operations centers are active in the Distrito Central, where victims are mistreated, questioned and then abandoned.

18 Official Gazette (Diario Oficial la Gaceta) of April 30, 2010. Year CXXXIII, Number 32,200.

19 Coordinator Eduardo Stein, former Vice-President of Guatemala, Michell Kergin, Canadian diplomat, Maria Amadilla Zavala Valladares, former Peruvian Judge, Julieta Castellanos, UNAH Dean, Omar Casco former UNAH Dean, Sergio Mmbreño, technical member, Craig Kelly, Undersecretary of State, and Julissa Reynoso, Deputy Assistant Secretary for Central American and Caribbean Affairs at the U.S. Department of State.

20 The technical assistance of the OAS is led by Bolivian Victor Rico, with the rank of Ambassador. 
Given the shortcomings displayed by the government's Truth Commission, which does not meet the international standards developed over the past decades to investigate political crimes, Human Rights organizations in Honduras initiated, set up and launched on June 28, 2010, the Comisión de Verdad (Truth Commission), composed by national and international representatives: Adolfo Perez Esquivel, 1980 Nobel Peace Prize winner, Argentina; Father François Houtart, Belgium; Luis Carlos Nieto, Spain; Craig Scott, Canada; Nora Cortinas, Argentina; Elsy Monge, Ecuador; Mirna Perla Jiménez, El Salvador; Francisco Aguilar, Costa Rica; and Helen Umaña and Father Fausto Milla, Honduras. Their objective is to help clarify the facts, ensure the moral recognition of victims of human rights violations and make recommendations to ensure that human rights violations do not re-occur. The Commission members filed their report in late 2011 and reported on their progress in June 2011.

As we noted earlier, Honduras remained under the scrutiny of international human rights bodies; in March the UN Office of the High Commissioner for Human Rights (OHCHR) concluded in its report that "The coup d'état gave rise to a number of human rights violations, most of which remain unpunished. In addition, it revealed and exacerbated existing structural problems affecting human rights, intensified a difficult and tense political and social climate, and deepened the polarization within most State institutions and society at large. Measures imposed under the state of emergency facilitated the repression of those opposed to the coup and allowed the arbitrary restriction of fundamental rights".

In its follow-up visit in May 2010, the Inter-American Commission on Human Rights found that there remains in Honduras a pattern of disproportionate use of public force and control of information aimed at restricting the political participation of the one sector of the public associated with the Resistance. The number of deaths and of people threatened and exiled because of political oppression is not exactly known. The hunger strike staged by judges who were dismissed for being philosophically opposed to the coup confirms that neither the Supreme Court nor prosecutors are fulfilling their constitutional mandate. Their actions have not only supported and strengthened the pervading unlawfulness but also have left a sector of the population totally legally defenceless. Meanwhile, the situation is worsening in terms of generalized violence (organized crime, crime, public insecurity), and the country has now reached an average of 66.8 homicides per hundred thousand inhabitants (WHO recognizes a global average of 10 per hundred thousand inhabitants). ${ }^{21}$

National Human Rights Commissioner Ramon Custodio Lopez called the IACHR report biased and intended to cause damage to Honduras, in order to drive away foreign investment. Custodio described the Commission as an instrument of the countries controlling the OAS because it is chaired by a Venezuelan national and the executive secretary is from Argentina. Custodio said that in Honduras there is complete freedom of speech, no political prisoners, and the media take advantage of freedom of expression. ${ }^{22}$ This response related to an IACHR news release that includes Honduras in the list of countries that do not respect civil rights.

$21 \quad$ According to information from the Observatory on Violence, in 2009 there were 8,154 violent deaths, of which 5,265 were homicides. The highest rates per 100,000 inhabitants were recorded in the departments of Cortes, 111.2, Atlanta: 106 and Columbus: 84.0

22 Diario la Prensa, April 16, 2010. 
Amid the ongoing political crisis, the state's fiscal bankruptcy and the social unrest caused by the failure to meet many basic human needs-including food and security-the Organization of American States is keeping out the State of Honduras, which is allegedly taking action to return to the Organization, focusing its efforts on the respect for human rights, combating impunity, the return to Honduras of former President Manuel Zelaya and a broad all-sectoral political dialogue, as established in the OAS report dated July 29, 2010. Time goes by... but the crisis deepens.

In November, the United Nations Human Rights Council resolution 5/1 opened the proceedings of the Universal Periodic Review (UPR) ${ }^{23}$ for the State of Honduras on human rights with a group of rapporteurs (the troika) composed of Thailand, United Kingdom of Great Britain, Northern Ireland and the Russian Federation.

The Honduran delegation ${ }^{24}$ presented the results of the November 2009 elections and reiterated the commitments of the Guaymuras Dialogue and Tegucigalpa-San José Accord, which provided for the establishment of a truth and reconciliation Commission, among other formalities.

The delegation reported that the National Congress was considering legislation to abolish the state of emergency, as it was incompatible with the Constitution. Article 209 of the Honduras Criminal Code, which regulates the crime of torture, was being reviewed with a view to harmonization with international human rights standards. He also stated that the National Congress included the bill on the judiciary, the Council of the Judiciary and the Judicial Service Act. Honduras was also promoting the incorporation of new legal institutions into the domestic legal framework, including the incorporation into the new Criminal Code of crimes recognized under international humanitarian law. The delegation also reported that since June 28, 2009, the Office of the Special Prosecutor for Human Rights has dealt with six cases of proven abuse against the media by police and military authorities

Other cases were being investigated. The State was planning a strategy to protect journalists, social communicators and human rights defenders with a view to protecting their lives and physical integrity, as well as ensuring the effective investigation of such offences. Honduras had asked for assistance from other countries to support the investigative functions.

23 Instrument of the new Council to monitor and assess the degree of compliance with States' international obligations regarding human rights. The assessment is based on information provided by the State being assessed, the Office of the High Commissioner for Human Rights and other stakeholders, which include civil society organizations. The end result of the UPR is a report with conclusions and recommendations, which may include or refer to any human rights obligation that the State has made.

24 María Antonieta de Bográn, Presidency Minister, Mario Canahuati, Minister of Foreign Affairs; Áfrico Madrid, Minister of the Interior; María Antonieta Botto, Minister for INAM (National Institute for Women); Alejandrina Pineda, Minister for Justice and Human Rights; Members Orle Solís and Welsin Vásquez; Prosecutors Sandra Ponce (of Human Rights), Yani del Cid (for Ethnic Groups), Nora Urbina (for Children), and Grisel Amaya (for Women). Also, Ricardo Rodríguez, Deputy Attorney General of the Republic. 
However, the arguments of the delegation of Honduras and its reluctance to accept that human rights violations are structural and politically motivated, along with the lack of willingness to combat impunity: of the 129 recommendations issued by 21 nations, Honduras accepted 5, indicated that 112 were in progress and said it would respond to 12 in March 2011. The following are some of the recommendations made during the review:

\section{[Translation]}

"That [Honduras] take the necessary measures to investigate and punish the violations of human rights committed in the aftermath of the coup d'état." That it adopt effective measures to protect journalists, human rights defenders, social communicators, including community radio stations. "All human rights violations, including killings of journalists, must be immediately and impartially investigated - Those responsible should be brought to justice." "That it guarantee pluralism and diversity, especially in the audiovisual media." Similarly, that it establish a legal and institutional framework to protect freedom of expression through the decriminalization of defamation and other content restrictions, as well as the proper implementation of access to information legislation.

The State of Honduras avoided referring to the coup and its consequences for human rights. Likewise, it declined to comment on the failure to investigate cases of murder, torture, abductions and illegal detentions for political reasons as well the existence of structures that are parallel to state security forces and operate with their consent and agreement. However, it did highlight an amnesty law that promotes impunity for civilians and military officers linked to the coup d'etat and the integration of senior military officers in the civilian structures of the Executive. Similarly, it failed to report that the National Congress is discussing a bill that criminalizes social protest and the work of human rights defenders-the terrorism bill.

The State also failed to report that prosecutors' offices in the Office of the Attorney General did not conduct investigations and relied on information illegally obtained by the Police to charge defenders and social activists. In most cases, the Police had participated in capturing and physically assaulting these victims. ${ }^{25}$

The regime leadership in the National Congress (where over 50\% of Members participated in the 2009 coup) continued passing legislation affecting the human rights of vast sectors of the nonorganized population, especially t the community and trade/professional union sectors.

25 Charges against 127 persons during 2009, for the offences of sedition, terrorism, aggravated arson, unlawful assembly and illegal demonstrations. 


\section{Education and labour rights}

The profound crisis that is shaking up the Honduran education system is another major problem facing the Lobo Sosa government. Over the past year, protests, general strikes and days of protest by students and teachers have laid bare the negative impact of the coup d'état mentality on educational affairs, and during the demonstrations by teachers making demands, there were clashes between educators, students and the police that have led to numerous arrests and injuries. Students are demanding the repeal of an education law introduced in the National Congress by the dictator Roberto Micheleti and teachers are demanding respect for the Teachers' Statute, an increase in the minimum wage and the return of more than 4 billion lempiras to the coffers of the Teachers' Social Security Institute.

The significant predicament of the Honduran education system worsened during the second half of 2010. Protests, general strikes and days of protest by students and teachers testify to the failures of the educational model that is unevenly contrasted with the budgets for security and defence. During the demonstrations, clashes between students and police have resulted in numerous individuals arrested, injured and prosecuted.

One of most recent points of disagreement is the General Education Act bill, an instrument consisting of over 100 articles that was developed by the National Convergence Forum (FONAC) between 2004 and 2009. The bill, which replaces the Education Act of 1966, had already caused tension between teachers and the Secretary of State for Education under President Zelaya. In 2009, the bill was not tabled in Congress because teachers' associations argued that there was still no agreement on it.

However, in May 2010, the Lobo government took up the bill again and referred it to the National Congress for discussion. Among other hot buttons in the bill, teachers' organizations question the requirement for teachers to have a university education in order to enter the education system, and the creation of a National Council on Education that would be responsible for defining the educational policies of Honduras, including those on higher education.

This point has been discussed by various sectors in light of the incongruence with the regulations of the National Autonomous University of Honduras (UNAH), the institution that has for years been responsible for defining the country's policies on higher education.

In late 2010, the National Congress issued a legislative decree whose text suspended the Teachers' Statute. Decree 136-2010 was published in the official gazette La Gaceta on December 28. Article 136 of the Decree reads as follows: "As of the date of entry into force of this Decree, Legislative Decree No. 174-2000 dated 30 October 2000, which contains the Honduran Teachers' Statute Law 26; Executive Agreement No. 0021-P.E.-2009 dated 20 November 2009; and Legislative Decree No. 151-2009 dated 26 December 2009, which contains the National Risk Management System Law (SINAGER), are suspended." 
The Decree was to contain de-indexing minimum wage increases for the professional statutes. The law passed on 27 October 2010 provided for the following wording: "Adopt transitional emergency measures to the effect that the established minimum wage should not be used as a reference for automatic and direct increases in the wages paid to public servants regulated by special laws or professional statutes."

Article 3 reads: "The economic systems established in the different professional statutes shall be put on hold during the term of this Decree." At the end of this report, the National Congress, through Luis Berrios Segovia, ${ }^{27}$ President of the Legislative Commission on Education, argued that this was a mistake that would be corrected through the publication of errata ${ }^{28}$ that would take place on January 24, 2010. Legislative Decree No. 174-2000 contains indexing of the minimum wage for the Teachers' Statute. The Teachers' Statute was approved by Decree No. 136-97 of 11 September 1997. Professional associations demonstrated publicly in San Pedro Sula and Tegucigalpa against the drafting of the Decree. Those demonstrations were suppressed, and four teachers were prosecuted.

On June 7, National Congress President Juan Orlando Hernández Alvarado introduced the Work and Opportunity Activation Program (PACTO). The program consists of six bills of law: the Law on Legal Immigration for Workers, the Hourly Employment Law, the Law on Generation of Rural Employment in Marginalized Urban Areas, the Law regulating the Public-Private Association System, the approval of contracts for renewable energy, and Law on Promotion and Protection of Investment. Approval was to take place on an emergency basis. The program was supported by the Honduran Council on Private Enterprise and the Chamber of Commerce and Industry of Tegucigalpa. ${ }^{29}$

Under the framework of this initiative, the Hourly Employment Law was passed on 4 November 2010 and is to remain in effect for 36 months with a possibility of extension. The three labour unions $^{30}$ began protesting against the law in August because it undermines the labour rights of workers and trade union rights. The ILO said that these laws violated Conventions 98 and 87 on freedom of association and the right to organize, and also violated labour stability $[\ldots]$ minimum wage. In October, the ILO presented recommendations on the need to add a provision to the bill to clearly indicate that the workers covered by the program enjoyed the fundamental rights and guarantees established in the Constitution and the ILO conventions ratified by Honduras. According to the writers of the bill, those rights were fully incorporated, but the labour unions differ on that point and are of the opinion that the views of the international body were manipulated.

\section{$27 \quad$ Tiempo newspaper, page 10, 22 January 2011}

28 Erratas must refer only to small errors in the text (e.g., errors of writing, spelling or punctuation. By contrast, if a significant error is detected in the construction of a text, or if the construction is such that the idea transmitted by the text is obscure or distorted to the point that it is confusing or erroneous, this error must be corrected within the book or document and not by means of an errata.

$29 \quad$ La Tribuna newspaper of 8 June 2010.

$30 \quad$ Press release of 13 August 2010, San Pedro Sula. 13 August 2010. UNITARY

CONFEDERATION OF WORKERS OF HONDURAS (CUTH), CONFEDERATION OF

WORKERS OF HONDURAS (CTH), GENERAL UNION OF WORKERS (CGT) and press release dated 3 November 2010. 


\section{Concessioning of Natural Resources}

Under the framework of the Work and Opportunity Activation Program, the Honduran Congress approved the Law for the Promotion of Electric Energy with Renewable Resources. This legislation has had environmental, social and economic impact in the country since 1 June 2010. In single debates, Congress approved 47 Contracts for the Use of National Waters for the Generation of Energy through Hydroelectric Projects.

Environmental organizations and organizations defending the rights of ethnic peoples complained that those communities were not taken into account during the concessioning of the rivers (47 concession projects). Some $70 \%$ of those concessions were bid on by business owners who are also owners of the thermal power industries.

Moreover, the law does not take account of the categorization of the National Environmental Assessment System, regulations that are also seriously challenged by the Environmental Law Institute, and against which an appeal for amparo [protection of constitutional rights] was filed that was not admitted by the Supreme Court of Justice. The 47 approved contracts ${ }^{31}$ will use the water resources for thirty years. The Law states that the concessioning of rivers can be from 10 to 50 years.

Also approved during the first semester was the Law on Promotion of Public-Private Partnerships that grants rights to immovable property_-protected areas and archaeological sites - in the form of concessions. Under this framework, and with the stated financial crisis and the Work and Opportunity Activation Program as a backdrop, the Ministry of External Relations launched a Web site entitled "Honduras Open for Business" (Honduras está abierta a los negocios). The Web site provides information on the national legal framework for investing, including the Law on Promotion of Public-Private Partnerships. Later, and before Lobo had been in government for one year, Congress

DECREE No. 46-2010 of 1 June 2010. CONTRACT FOR THE USE OF NATIONAL WATERS FOR THE GENERATION OF ENERGY THROUGH THE EL SUEÑO II HYDROELECTRIC PROJECT, signed by the Secretary of State for Natural Resources and Environment (SERNA) and the hydroelectric energy company BLUS S.A. DE C.V. The purpose of the Water Contract is the use of national waters from the natural basin of the River Palaja located in the municipality of El Míspero, Department of Santa Bárbara. (SERNA) (Proceedings 26) DECREE No. 47-2010 of 1 June 2010. CONTRACT FOR THE USE OF NATIONAL WATERS FOR GENERATION OF ENERGY THROUGH THE MORJA HYDROELECTRIC PROJECT located in the municipality of El Paraíso, Department of Copán, between the corporation INGENIERÍA TÉCNICA, S.A. DE C.V. (SERNA) (Proceedings 26) DECREE No. 48-2010 of 1 June 2010. OPERATING CONTRACT FOR THE GENERATION OF ELECTRICAL POWER AND ENERGY FOR THE ESTABLISHMENT OF THE “LAS VENTANAS” POWER STATION located in the Cuenca del Río Uluita in the municipality of Jesús de Otoro, Department of Intibucá, signed in the city of Tegucigalpa, Municipality of the Central District, on 4 December 2009, between the company PROVEEDORES INTERNACIONAL, S.A. (PROINTER). (SERNA) (Proceedings 26). 
approved the law on Special Development Regions popularized as the "Model Cities" that are to be established in Agalta, Olancho; Trujillo; Ocotepeque and Amapala.

Dismantling of social organizations and attacks on human rights defenders

In 2010, the measures for dismantling social organizations were strengthening. On 18 November 2010, the National Congress passed the Law against the financing of terrorism. Known as the Anti-terrorist Law, and containing 83 articles, it seeks to increase land, air and sea customs controls. It will likewise force non-governmental organizations to report any donation or support over two thousand dollars ${ }^{32}$ to the government. This includes the lending of vehicles or equipment. The law also provides for fines of 2000 times the minimum wage, prohibition of activities for five years or dissolution of the association. The provisions contained in this new law do not comply with international standards in procedural matters.

The impunity surrounding the deaths of journalists has made Honduras the second most dangerous country for practising critical journalism after Mexico. However, it also shows signs of the modus operandi of clandestine commandos that are very similar to the Colombian model. Until 2010, there was no pattern of murders of journalists as an attack on freedom of the press, expression and information. Ten journalists have been killed since March 2010. Violence and threats, as well as the current government's information policy and self-censorship have caused a deficit of information and expression in Honduras. The year 2010 also saw the arbitrary arrest and prosecution of members of the media for doing their work.

Impunity also allowed widespread intimidation and spying against other actors including human rights defenders. Illegal actions included intercepted phone calls and emails, following, harassment and threats, information theft and illegal enries into offices and homes. This led to an atmosphere of insecurity and sometimes fear of sabotage and discrediting of the work of human rights defenders. Actions against women included direct threats against their sons and daughters, sometimes with clear violent sexual content.

After observing the various violations of fundamental human rights, we can see that they are focussed on replicating the "Colombian model": Democratic Security Policy, which includes geographic militarizations, stigmatization of opponents, accusations against national and international human rights organizations of defending terrorism, fragmentation of society, intimidation of journalists, issuance of laws to combat terrorism, incorporation of political repression into the justice administration system, and intimidation of political opponents and civil society by through attacks on relatives, among other methods of repression. 
TABLE SUMMARIZING STATISTICS ON HUMAN RIGHTS VIOLATIONS: 31 JANUARY 2010 TO 31 JANUARY 2011

The Honduran government is pressing forward with the dismantling and death of those who opposed the coup d'état and form the Resistance. The armed actors are becoming stronger in their actions of devastation and death. The lack of effective response by the courts increases that cycle of impunity and the outlook is worsened by the silence and the terror that has been imposed in the country. The figures that are reborted are linked to violations of human rights for political reasons during the period Januarv 2010 to Januarv 2011. Information recorded by COFADEH (Committee of Relatives of Disappeared Detainees in Honduras)

\begin{tabular}{|c|c|c|}
\hline RIGHT VIOLATED & Quantity & Comments \\
\hline Political assassinations & 34 & \\
\hline Murders over land disputes & 34 & \\
\hline Murders due to abuse of authority & 28 & \\
\hline Suspicious deaths & $309 *$ & $\begin{array}{l}\text { Accroding to the UNAH observatory on violence and The United Nations } \\
\text { Development Programme in Honduras, there are } 10 \text { to } 15 \text { murders daily } \\
6236 \text { in } 2010,1240 \text { more than in } 2009\end{array}$ \\
\hline Attacks against persons and property & 23 & \\
\hline Death threats & 274 & 133 threats against human rights defenders \\
\hline Intimidation and persecution & 77 & \\
\hline Sexual assaults & 2 & \\
\hline Kidnappings & 5 & \\
\hline Attempted kidnappings & 7 & \\
\hline \multicolumn{3}{|l|}{ RIGHT TO INTEGRITY } \\
\hline Injuries and beatings & 96 & \\
\hline Torture & 26 & \\
\hline \multicolumn{3}{|l|}{ RIGHT TO INVIOLABILITY OF THE HOME } \\
\hline Raids & 23 & \\
\hline Neighbourhoods and districts subject to searches & 24 & Neighbourhoods and districts profiled by the security forces as Resisters \\
\hline \multicolumn{3}{|l|}{ FREEDOM OF MOVEMENT AND RESIDENCE } \\
\hline CIDH precautionary measures* & 160 & People to which the Commission has granted precautionary measures. \\
\hline CIDH precautionary measures * & 19 & Organizations to which the IACHR has granted precautionary measures \\
\hline Request for information $\mathrm{CIDH}{ }^{*}$ & 33 & Cases on which the IACHR has requested information from the government. \\
\hline Informatics theft & 11 & \\
\hline \multicolumn{3}{|l|}{ FREEDOM OF EXPRESSION } \\
\hline Murdered journalists & 10 & \\
\hline Attacks against journalists & 1 & \\
\hline Threats against journalists and social & 22 & \\
\hline Illegal detention of journalists and social & 4 & \\
\hline Attacks on journalists and members of the media & 5 & \\
\hline Exiled journalists & 6 & \\
\hline
\end{tabular}




\begin{tabular}{|l|c|l|}
\hline Closed programs & 1 & \\
\hline Community radio closed & 2 & \\
\hline Attacks on media & 6 & \\
\hline RIGHT TO JURIDICAL PERSONALITY AND & & \\
\hline Reprisals & 10 & Four teaching schools and six unions \\
\hline TOTAL & $\mathbf{1 6 5 8}$ & \\
\hline
\end{tabular}

table prepared by CED-COFADEH 


\title{
Contexto Nacional en Materia de Derechos Humanos
}

adaptado del 1er capítulo del

\section{Informe Situación de Derechos Humanos en Honduras: enero 2010 a enero 2011 (marzo 2011)}

\author{
por el Comité de Familiares de Detenidos-Desaparecidos de Honduras - COFADEH
}

La situación general de los derechos humanos en Honduras durante 2010 continúo siendo de emergencia debido a las vulnerabilidades político - institucionales consecuencias del golpe de Estado Militar. Particularmente la vida, participación política y disidencia, libre expresión y derecho a la información; justicia e igualdad, tenencia de la tierra y alimentación, fueron derechos violados en forma sistemática.

Las actividades de sicarios en operaciones clandestinas de tipo policial-militar, el empoderamiento financiero y político de las fuerzas de seguridad del Estado y el avance territorial y cultural del crimen organizado, continuaron teniendo un grave impacto sobre los derechos humanos.

Aunque en el discurso oficial hay un énfasis fuerte contra las actividades del narcotráfico y el crimen organizado, en la práctica los agentes del Estado combaten las actividades de la resistencia al golpe militar y el trabajo de consolidación del Frente Nacional de Resistencia Popular, focalizando especialmente a la juventud.

El fenómeno nuevo del paramilitarismo ${ }^{33}$ tiene espacios de actuación autónoma en el terreno, especialmente en las márgenes del río Aguán y en los valles de Santa Barbará (Quimistán, Azacualpa, Macuelizo, Sula y otros), causando múltiples crímenes y sembrando zozobra y terror. Los grupos clandestinos operan contra defensores de derechos humanos y grupos de sociedad civil, incluyendo defensorías de mujeres, sindicalistas, periodistas y ONGs, que han enfrentado ataques contra sus sedes y sus propias vidas.

Además en la misma lógica fue desarrollado un discurso público intimidatorio por funcionarios de seguridad y defensa que equiparan en forma maliciosa y tendenciosa el trabajo de defensa y promoción de derechos humanos con actividades de organizaciones terroristas ${ }^{34}$, poniendo en riesgo la integridad física de sus impulsores.

33 Alfredo Jalife, geopolitólogo mexicano define los paramilitares como una creación de los gobiernos totalitarios que están en guerra. Explica que, de esta manera, "el Estado disfraza sus peores intenciones", que ejecuta a través de estos cuerpos paramilitares que son ex milicianos o ex criminales, o personas que sirven precisamente a los intereses aviesos.

34 El día 14 de diciembre de 2010, se publicó en el diario "El Tiempo" de San Pedro Sula, una nota periodística señalando que: el Secretario de Seguridad Oscar Álvarez responsabilizó a organizaciones de derechos humanos como el Comité de Familiares de Detenidos y Desaparecidos en Honduras (Cofadeh) de prestarse a desestabilizar el actual gobierno y apoyar estos grupos armados del Bajo Aguán, por lo que fiscales y jueces están listos para encarcelar a los organizadores de la toma. afirmaciones también circularon en medios de comunicación radial 
Fue especialmente preocupante el robo de información relacionada con un caso de torturas a una abogada del Cofadeh, por personas desconocidas. En algunas ocasiones, la información obtenida de forma ilegal por la fuerza de seguridad pública fue utilizada por algunas de las Fiscalías para abrir procesos judiciales contra defensores de derechos humanos y activistas sociales ${ }^{35}$.

No obstante que la Comisión Interamericana de Derechos Humanos, que visitó Honduras en el mes de mayo de 2010, demandó del Estado asegurar que los defensores de derechos humanos fueran adecuadamente apoyados y protegidos, su situación siguió siendo vulnerable.

La comunidad LGTB, incluyendo sus liderazgos, ha sido blanco de persecución y crímenes de odio. Registran 25 asesinatos en el año 2010, mientras que las organizaciones indígenas y garífunas documentaron amenazas a muerte y ataques sistemáticos contra sus patrimonios ancestrales y sedes.

En la casi totalidad de los hechos la impunidad continúa siendo la característica principal, lo que evidencia la disfuncionalidad de las instituciones del Estado de Derecho y el grave riesgo en que se encuentran las víctimas y sus entornos familiares y organizativos. En un contexto así, de violencia, inseguridad e impunidad, los riesgos son muy altos para el ejercicio de la libertad de expresión, pensamiento e información, igualmente para los derechos sindicales, gremiales y de protesta colectiva.

Y nada peor que ser joven bajo sospecha de infracción de la ley, asociación ilícita o militancia resistente, son las principales víctimas en la estadística del levantamiento diario de más de 16 cadáveres en el territorio nacional.

En el telón de fondo de las violaciones a los derechos humanos está el reposicionamiento del militarismo en la política, que es visible en el presupuesto nacional, en la ocupación de instituciones del Estado de donde habían sido expulsados, en la logística que exhiben en calle, el discurso público de los jefes castrenses y las actitudes recias, abusivas y prepotentes en el relacionamiento con la ciudadanía.

La cúpula militar - policial participante en el golpe fue uno de los primeros sectores beneficiados por un fallo del poder judicial en los primeros meses del régimen de Lobo Sosa, agregándole una sobredosis de desconfianza a las frágiles instituciones públicas existentes aún.

En 18 meses el militarismo arribó de nuevo como un contravalor en la sociedad hondureña, paralelo al poder instituido y causante de violaciones a los derechos humanos. La presencia del general Romeo Vásquez Velásquez en la empresa pública de telecomunicaciones, Hondutel, confirma las intenciones económicas, políticas y estratégicas de los uniformados a partir del golpe militar, hasta nuestros días; igualmente, en Migración y Marina Mercante.

35 Caso Defensores y periodistas de Coyotito Zacate Grande 15 de diciembre de 2011. Maestros criminalizados 20 de agosto de 2010 
En los últimos 10 meses al menos cuatro instituciones ${ }^{36}$ fueron militarizadas y dos decretos de militarización geográfica fueron emitidos. El Gobierno acordó, además, desplegar más de mil efectivos en las calles con el supuesto objetivo de combatir la violencia, a los cuales se sumaron otros dos mil 500 militares y policías en el norte del país, donde también se inauguró una base naval.

En este punto de fractura democrática, en el que los militares sí han asumido funciones ejecutivas, de presión política en el Congreso Nacional y en la Corte Suprema de Justicia y de violencia contra la disidencia política resistente, retomamos las afirmaciones hechas en los primeros seis meses de 2010 .

Los hechos hablan con dureza del déficit democrático, la pérdida de confianza y legitimidad en las instituciones, de los formalismos jurídicos que aseguran impunidad y de la regresión de los derechos humanos en materia laboral y económica.

\section{La continuación del Golpe Militar del Estado}

El segundo periodo del Golpe de Estado comenzó el 27 de enero de 2010, después de las "elecciones generales" realizadas entre los fusiles del Ejército, sin libertad de expresión y sin observación internacional. La expresión más visible de esta nueva fase de rompimiento institucional fue el aumento drástico de la represión y nuevas formas de control de la oposición. El régimen cívico militar dictatorial asienta su estilo sobre la impunidad de los actores políticos del 28 de junio de 2009, concediéndoles puestos estratégicos de la administración pública, profundizando así la crisis de legitimidad del Estado y las elites.

La obsesión por el reconocimiento internacional del régimen sucedáneo aumentó la represión selectiva contra líderes sociales de la resistencia popular; los primeros en sufrir la ofensiva fueron los movimientos sociales de carácter intermedio, el movimiento obrero, lo mismo que los movimientos campesinos que enfrentaron la oferta armada del Ejército y la Policía, además de las presiones de los agroindustriales y del terrorismo mediático, que frenaron las reformas agrarias integrales que habían sido proyectadas a principios de 2009.

El golpe de Estado ancló en el país los antivalores del autoritarismo, la intolerancia, la negociación con garrote, el incumplimiento de la palabra empeñada y el irrespeto a las diferencias, que se tradujo hasta la fecha en métodos violentos para enfrentar la conflictividad social y política con grupos privados radicales y cuerpos militares represivos, desdibujando aún más los escombros del Estado de Derecho. Esto es ingobernabilidad, con agravantes de fundamentalismos religiosos y terrorismo mediático que no solamente imponen dogmas y prejuicios, sino que desconocen, insultan o descalifican a la oposición social y política, generando lógicas de guerra psicológica e inclusive ataques sectoriales, removiendo las heridas subyacentes en el tejido social.

La ruptura del régimen democrático profundizó la impunidad de las décadas anteriores hasta convertirla sin rituales en política de Estado, lo que resquebrajó hasta la médula la débil e incipiente institucionalidad levantada después de los regímenes cívico militares golpistas anteriores. A la vez, esta involución democrática también se expresa en corrupción de la justicia, desconfianza por la

36 Agosto de 2010, la UNAH, Agosto de 2010, INPREMAH, Noviembre de 2010, El Instituto Nacional Agrario en Sinloa y Las instalaciones del COPEMH en Tegucigalpa. 
deficiencia y negligencia de la policía y el Ministerio Público, cada vez más percibidos en su proximidad con las élites golpistas y bandas del crimen organizado, que violan la vida, la libertad y depredan los recursos naturales. No hay duda que en Honduras está instalada una dictadura. En este contexto, los derechos civiles y políticos sufren su peor embestida desde el Estado, y algo peor ocurre a los derechos económicos, sociales y culturales, sometidos a la regresión por la vía administrativa del Ejecutivo y del Congreso Nacional, donde se legisla contra la progresividad.

El sector privado y político que dio el golpe y que lo continúa en el régimen sucedáneo porfía en mantener vivo el modelo neoliberal fracasado. Reducir el Estado a la mínima expresión y conceder la iniciativa a los mismos grupos empresariales que controlan las instituciones. Privatizar o concesionar es la orden del día. Eliminar subsidios a los pobres. Exonerar a los grupos con poder y aumentar sacrificios fiscales a los asalariados. No aumentar salarios a los empleados públicos e irrespetar la ley del Salario Mínimo al pretender cambiar el aumento anual obligatorio por un bono inferior a los mil dólares.

En el agro, los conflictos por el recurso tierra y agua, se agudizan. Hay muertos y heridos en esta confrontación creciente. En la Zona del Aguán la negociación con militarización caracteriza el escenario: entre abril y septiembre han sido asesinados 11 campesinos por autoridades y paramilitares, mientras se cumple parcialmente un acuerdo de distribución de tierras entre el Movimiento Unificado del Aguán (MUCA) y el señor Porfirio Lobo. En la zona prevalece un clima de terror.

Por otro lado las cargas tributarias aprobadas por el Congreso Nacional, en marzo de 2010, se convirtieron en una nueva fuente de conflicto al generar descontento aparente entre los propios empresarios y, desde luego, en la población trabajadora. El paquete fiscal denominado "medidas tributarias" y la declaratoria de una emergencia financiera y fiscal está dirigido a los contribuyentes de los impuestos sobre ventas, renta y selectivos al consumo, de igual forma a la importación de vehículos, los pasajes aéreos, e impuesto gradual al servicio telefónico, abonados de energía eléctrica antes subsidiados por acto administrativo de órganos desconcentrados pagarán tarifas de 200 Lempira o más.

Mientras los defensores y defensoras de derechos humanos, periodistas, activistas sociales, opositores políticos y resistentes al golpismo sufren acechanzas y persecuciones, las organizaciones internacionales (OEA, ONU, UE) y sus órganos políticos fracasaron en restaurar el orden institucional y estimularon la violencia generalizada y el crimen organizado al proponer inútilmente un pacto de élites, que desconoce al sujeto social, al pueblo organizado. Sin duda que el crimen organizado avanzó sobre los escombros del Estado de Derecho y penetró a través de organizaciones de fachada.

El país tras el parteaguas del 28 de junio 2009 está representado en la Unión Cívica Democrática, que agrupa a los empresarios y políticos responsables del golpe de Estado, y el Frente Nacional de Resistencia Popular, que propone la restauración del orden democrático por la vía de la Asamblea Nacional Constituyente.

En este panorama, la clase política dominante perdió el control de las fuerzas y movimientos sociales que en el pasado manejó. El equilibrio político se resquebrajó. El bipartidismo se auto 
golpeó. Pero el Frente Nacional de Resistencia nació y creció con campesinos, sindicatos, pobladores, profesionales, maestros, estudiantes, jóvenes, mujeres organizadas, indígenas, vendedores ambulantes y enfrenta, en respuesta, una cruenta represión con crímenes de persecución política y crímenes de odio.

No obstante que el país continuó bajo la mirada de los organismos internacionales de derechos humanos, Porfirio Lobo Sosa, poco después de asumir la Casa Presidencial, firmó un Decreto de Amnistía, tal como lo habían venido exigiendo desde julio de 2009, para favorecer únicamente a las fuerzas que gestaron, organizaron y ejecutaron el golpe de Estado ${ }^{37}$. Decreto que firmó en medio de su discurso de toma de posesión. Así mismo sancionó los Decretos de Plan de Nación 2010 - 2038 y Visión de País 2010 - 2022, destinados a ejecutarse durante los próximos siete periodos de gobierno. El plan de continuidad del neoliberalismo salvaje.

Este último documento que se comenzó a trabajar el 25 de noviembre de 2009, carece de consulta, legitimidad y participación, de igual forma no tiene como objetivo la reducción de las desigualdades sociales y el desarrollo económico de la población, por el contrario mantiene seguros los intereses de los grupos de poder en el largo plazo.

\section{La Militarización y la Remilitarización de Honduras}

Tres días más tarde de la toma de posesión, el 30 de enero suscribió un convenio en materia de seguridad con el Presidente de Colombia, Álvaro Uribe, convenio que entró en vigencia el 15 de febrero de 2010. En esa fecha, Oscar Arturo Álvarez Guerrero, Secretario de Seguridad de Lobo, se reunió en Colombia ${ }^{38}$, con el Canciller de ese país, el vicepresidente Francisco Santos, el director del Departamento Administrativo de Seguridad (DAS, inteligencia estatal), Felipe Muñoz, y el director de la Policía Nacional, General Óscar Naranjo. La cooperación de Colombia estaría orientada a la creación de unidades de inteligencia, contrainteligencia, antinarcóticos, terrorismo, antisecuestros, trata de personas, abuso de menores de edad sometidos a la prostitución, delitos cibernéticos, y otros, a través de diferentes instituciones, entre las que figuran la Fiscalía de Derechos Humanos, las secretarías de Seguridad y Defensa, la Dirección de Lucha contra el Narcotráfico y el Poder Judicial.

El 27 de mayo de 2010, Porfirio Lobo suscribió un Convenio con el Perú, sobre la cooperación en materia de producción, prevención del consumo, rehabilitación, control de tráfico ilícito de drogas, sustancias sicotrópicas y delitos conexos. Y el acuerdo de cooperación para la prevención, represión y lavado de activo derivado de cualquier actividad ilícita.

El 14 de abril de 2010, Honduras y Estados Unidos firmaron un convenio por 4.4 millones de Dólares para apoyar la lucha contra el crimen a través de entrenamiento y equipo para la Policía, a fin de incrementar su capacidad para combatir el narcotráfico, las maras, los secuestros y el tráfico

\footnotetext{
$37 \quad$ Decreto Legislativo 2-2010

38 Canciller de Colombia Jaime Bermúdez, firmo el nuevo acuerdo, por medio del cual se compartirá "la exitosa" experiencia en materia de seguridad y contra la delincuencia organizada en el marco de la cooperación sur-sur.
} 
de armas. Millones que serán canalizados por el proyecto Barrio Pobre ${ }^{39}$. Este convenio fue firmado en la Colonia San Miguel de Tegucigalpa, en presencia del Ministro de Seguridad, Oscar Álvarez; el director de la Policía Nacional, José Luis Muñoz Licona, el alcalde de Tegucigalpa, Ricardo Álvarez, miembros de la Policía y líderes comunitarios. La estructura de fortalecimiento de los aparatos de inteligencia y represión.

En el mes de Julio, el Embajador estadounidense Hugo Llorens informó a la prensa que Fiscales y miembros de la Unidad Antisecuestros de la Dirección Nacional de Investigación Criminal (DNIC) participarían en un programa de varias semanas, que permitirá mejorar su nivel profesional.

El 13 de abril de 2010, Profirió Lobo inauguró junto al Embajador de Estados Unidos en Honduras, Hugo Llorens, la nueva base militar naval en la Laguna de Caratasca, en el departamento de Gracias a Dios. Esta unidad militar tendrá supuestamente la misión de reforzar la lucha contra el narcotráfico de esa región hondureña. Las instalaciones fueron construidas por miembros del Ejército estadounidense y del Comando Sur, a un costo de dos millones de Lempiras. Constan de un edificio multifuncional y un centro de operaciones, lo que contribuye al aumento en la capacidad para albergar más personal, así como un nuevo muelle para el anclaje de lanchas interceptoras y de patrullaje ${ }^{40}$. En el 2009, Estados Unidos entregó en Puerto Castilla cuatro lanchas interceptoras con un valor de 2,6 millones de dólares.

El 18 de junio de 2010, el portal Infodefensa.com informó que Estados Unidos había decidido reanudar la ayuda militar a Honduras con la donación de 25 camiones al ejercito que fueron entregados por el subjefe del Comando Sur General Ken Keen, al Secretario de Defensa de Lobo, Marlon Pascua y al Jefe del Estado Mayor Carlos Cuellar. La donación asciende a 812,000 Dólares ${ }^{41}$.

En el mes de julio el Secretario de Relaciones Exteriores de Porfirio Lobo, informó a la prensa que construirán una nueva base militar que se ubicará en Guanaja, isla del Caribe hondureño, con el propósito de combatir el crimen organizado, tráfico de drogas y controlar todo el sector atlántico.

Según la información oficial en la base además de Estados Unidos, tiene interés Guatemala, El Salvador y México. En este ambiente de creciente militarización y la involución hacia un Estado policiaco, que genera alertas de riesgo social a sectores completos, para allanar ilegalmente la residencia de los ciudadanos que habitan los sectores más pobres.

La Busqueda de la Verdad y la Justicia

El Cofadeh conoció diferentes denuncias de víctimas de violaciones a derechos humanos que han revelado que fueron interrogados por personas que tenían acento suramericano durante su

39 Honduras y Estados Unidos firmaron en enero de 2009 el convenio de la iniciativa por medio del cual se le concedieron al país 3.6 millones de dólares de los 10 millones destinados a la región, a los que se sumaron los 2.8 millones concedidos en abril de 2010 por EE UU.

40 Lobo Sosa agradeció al presidente de los Estados Unidos, Barack Obama, "por este magnífico aporte, que es un gran paso al combate del narcotráfico y al crimen organizado".

41 Los camiones se asignaron a Batallón de las Fuerzas Especiales en la Venta y la BREA. 
cautiverio en centros de operaciones clandestinas ${ }^{42}$. Al mismo tiempo que se difundían denuncias de secuestros y el asesinato de sindicalistas, Porfirio Lobo encargaba al guatemalteco Eduardo Stein, la coordinación de una Comisión de la Verdad y Reconciliación, que indagaría los hechos relacionados al golpe de Estado del 28 de junio de 2009.

El 30 de abril de 2010, fue publicado el Decreto PCM -011-2010, que creó la Comisión de la $\operatorname{Verdad}^{43}$, a la que le falta componentes esenciales de verdad y justicia, autonomía, independencia y profesionalismo en derechos humanos; en su momento los organismos nacionales e internacionales de derechos humanos le apuntaron que su mandato no contemplaba la investigación en materia de violaciones a los derechos humanos; y que sus hallazgos no tienen consecuencias jurídicas, así mismo no incorpora la adopción de medidas de no repetición.

Todo proceso de justicia, que en el caso de Honduras no puede llamarse transicional porque todavía nos encontramos en el conflicto político, debe de reunir tres principios básicos: 1) la satisfacción del derecho a la verdad, 2) la satisfacción del derecho a la justicia, y 3) la satisfacción del derecho a la reparación, supuestos que en la comisión oficial de la verdad y reconciliación no se cumplen.

El artículo primero del Decreto 011-2010 establece como objetivo de la Comisión de la Verdad y Reconciliación "esclarecer los hechos ocurridos antes y después del 28 de junio del 2009 a fin de identificar los actos que condujeron a la situación de la crisis y proporcione al pueblo de Honduras elementos para evitar que estos hechos se repitan en el futuro".

Por si a la población le quedaba alguna duda sobre los alcances de esta comisión, el Señor Porfirio Lobo Sosa, declaró a los medios de comunicación "esta comisión no es para juzgar a nadie sino para buscar la reconciliación del pueblo hondureño". Las declaraciones de Lobo no dejan lugar a dudas que las estructuras armadas estatales y para estatales, que están generando graves violaciones a los derechos humanos no serán desmanteladas. Los altos funcionarios implicados en violaciones a los derechos humanos e implicados en el golpe de Estado no serán separados de las estructuras de la administración pública.

Así las cosas, el 04 de mayo de 2010, se instaló la Comisión de la Verdad44, en presencia de José Miguel Insulza, Secretario de la Organización de Estados Americanos ${ }^{45}$. Esta Comisión presuntamente presentara su informe en enero de 2011.

$42 \quad \mathrm{Al}$ menos en el Distrito Central operan cuatro centros de operaciones clandestinas, donde las víctimas son vejadas interrogadas y luego abandonadas

43 Diario Oficial la Gaceta del 30 de abril de 2010. año CXXXIII, Número 32,200.

44 Coordinador, Ex vicepresidente de Guatemala Eduardo Stein, Diplomático Canadiense Michell Kergin, la ex Magistrado Peruana Maria Amadilla Zavala Valladares. Julieta Castellanos, Rectora de la UNAH, Omar Casco ex Rector de la UNAH, Sergio Mmbreño como técnico, Subsecretario de Estado Craig Kelly y la Subsecretaria para Asuntos de América Latina y el Caribe Julissa Reynoso.

45 La asistencia técnica de la OEA es encabezada por el boliviano Victor Rico, con rango de embajador. 
Ante las debilidades que exhibe la Comisión de la Verdad gubernamental, que no reúne los estándares Internacionales formulados a lo largo de las décadas anteriores para investigar crímenes políticos, las organizaciones de Derechos Humanos de Honduras impulsaron, conformaron e instalaron el 28 de junio de 2010 la Comisión de Verdad, integrada por comisionados nacionales e internacionales: Adolfo Pérez Esquivel, Premio Nobel de la Paz 1980 de Argentina; sacerdote François Houtart, de Bélgica; Luis Carlos Nieto, de España; Craig Scott de Canadá; Nora Cortiñas, de Argentina; Elsy Monge de Ecuador; Mirna Perla Jiménez, de El Salvador; Francisco Aguilar, de Costa Rica; Hellen Umaña y el Padre Fausto Milla, de Honduras. Con el propósito de contribuir al esclarecimiento de los hechos, el Reconocimiento moral de las víctimas de violaciones de derechos humanos y la presentación de recomendaciones que garanticen la no repetición de las violaciones de derechos humanos. Los comisionados presentaran su informe a finales del 2011 y los avances en junio de 2011.

Como apuntábamos al inicio, Honduras continuó bajo la mirada de los organismos internacionales de derechos humanos, en marzo la Alta Comisionada de las Naciones Unidas para los Derechos Humanos (OACNUDH) concluyó en su informe que "El Golpe de Estado dio lugar a violaciones de derechos humanos, la mayoría de las cuales siguen impunes. Además, reveló y exacerbó problemas estructurales existentes que afectan a los derechos humanos, intensificó una atmósfera política y social difícil y tensa, y profundizó la polarización dentro de la mayoría de las instituciones del Estado y la sociedad en general. Las medidas impuestas con arreglo al estado de excepción facilitaron la represión de los que se oponían al Golpe y dieron lugar a la restricción arbitraria de derechos fundamentales".

Por su parte la Comisión Interamericana en su visita de seguimiento de mayo 2010, constató que "se mantiene en Honduras un patrón de uso desproporcionado de la fuerza pública y control de la información dirigido a limitar la participación política de un sector de la ciudadanía agrupado en la Resistencia. El número de víctimas fatales, personas amenazadas y exiliadas por la represión política no se precisa con exactitud. La huelga de hambre de los jueces despedidos por mantener un pensamiento contrario al Golpe de Estado confirma que ni la Corte Suprema de Justicia ni el Ministerio Público están cumpliendo con su mandato constitucional. Sus actuaciones no sólo han respaldado y fortalecido la ilegalidad sino que además se ha dejado a un sector de la población en total indefensión jurídica. Mientras tanto, en lo que atañe a la violencia común (crimen organizado, delincuencia, inseguridad ciudadana) la situación va en aumento y el país ya tiene un promedio de 66.8 homicidios por cada cien mil habitantes (la OMS reconoce una tasa promedio mundial de 10 por cada cien mil habitantes)" 46 .

El comisionado Nacional de derechos Humanos, Ramón Custodio López, calificó el Informe de la $\mathrm{CIDH}$ como manipulado y cuyo objetivo es dañar a Honduras, con el propósito de ahuyentar la inversión extranjera. Custodio calificó a la CIDH como instrumento de los países que controlan la OEA, porque está presidida por una ciudadana venezolana y el secretario ejecutivo es un argentino. Custodio afirmó que en Honduras hay completa libertad de expresión, no hay presos políticos, los

46 Según datos del Observatorio de la Violencia, en el 2009 hubo 8,154 muertes violentas y de ellas 5,265 fueron homicidios. Las tasas más altas por 100 mil habitantes se registran en los departamentos de Cortés: 111.2, Atlántida: 106 y Colón: 84.0 
medios de comunicación abusan de libertad de expresión ${ }^{47}$. Esta reacción está relacionada con el comunicado de prensa de la CIDH donde incluye a Honduras, como uno de los países latinoamericanos donde no se respetan los derechos civiles.

Entre la crisis política continua, la bancarrota fiscal del Estado y la agitación social por múltiples carencias humanas básicas - incluyendo comida y seguridad humana -- la Organización de Estados Americanos mantiene fuera de su seno al Estado de Honduras, que realiza supuestamente acciones para su regreso, todas vinculadas al respeto de los derechos humanos, la lucha contra la impunidad, el regreso del ex presidente Manuel Zelaya y el diálogo político pro constituyente, como lo establece el Informe de la OEA de fecha 29 de julio de 2010. El tiempo pasa... pero la crisis se agudiza.

En noviembre, la resolución 5/1 del Consejo de Derechos Humanos de las Naciones Unidas, abrió el procedimiento de Examen Periódico Universal (EPU) ${ }^{48}$ al Estado de Honduras en materia de derechos humanos con el grupo de relatores (troika) integrado por Tailandia, el Reino Unido de Gran Bretaña, Irlanda del Norte y la Federación de Rusia.

La delegación ${ }^{49}$ de Honduras expuso sobre los resultados de las elecciones de noviembre de 2009, repitió los compromisos del Diálogo Guaymuras y Tegucigalpa-San José, que establecía la integración de una Comisión de la Verdad y Reconciliación, y otras formalidades.

La delegación informó que el Congreso Nacional estaba considerando la posibilidad de abolir la legislación sobre los estados de emergencia, ya que era incompatible con la Constitución. El artículo 209 del Código Penal, que regulaba el delito de tortura, estaba siendo revisado con miras a su armonización con las normas internacionales de derechos humanos. Dijo también que el Congreso Nacional incluyó el proyecto de ley sobre el poder judicial, el Consejo del Poder Judicial y la Ley de Servicio Judicial, la incorporación de nuevas instituciones jurídicas en el marco jurídico nacional, incluida la incorporación en el nuevo Código Penal de los crímenes reconocidos bajo las leyes humanitarias internacionales. También informó que desde el 28 de junio de 2009, la Oficina del Fiscal Especial para los Derechos Humanos se ha ocupado con seis casos de abuso probado contra los medios de comunicación por la policía y las autoridades militares.

Otros casos estaban siendo investigados. El Estado estaba planeando una estrategia para proteger a los periodistas, comunicadores sociales y defensores de derechos humanos con el fin de proteger

$47 \quad$ Diario la Prensa del 16 de abril de 2010.

$48 \quad$ Herramienta del nuevo Consejo para vigilar y evaluar el grado de cumplimiento de las obligaciones internacionales de los Estados en materia de derechos humanos. La evaluación se basa en la información aportada por el Estado evaluado, la Oficina de la Alta Comisionada de las Naciones Unidas para los Derechos Humanos y otros actores interesados, donde se incluyen las organizaciones de la sociedad civil. El resultado final del EPU es un informe con conclusiones y recomendaciones, éstas pueden abarcar o referirse a cualquier obligación que el Estado haya asumido en materia de derechos humanos.

49 Ministra de la Presidencia, María Antonieta de Bográn, El Secretario de Relaciones Exteriores, Mario Canahuati; del Interior, Áfrico Madrid; del INAM, María Antonieta Botto; La Secretaria de Justicia y

Derechos Humanos, Ana Alejandrina Pineda; los diputados Orle Solís y Welsin Vásquez; las fiscales Sandra Ponce (de Derechos Humanos), Yani del Cid (de las Etnias), Nora Urbina (de la Niñez), y Grisel Amaya (de la Mujer). Y El Subprocurador General de la República, Ricardo Rodríguez. 
sus vidas y la integridad física, así como garantizar la efectiva investigación de tales delitos. Honduras había solicitado la asistencia de otros países para apoyar las funciones de investigación.

No obstante, los argumentos de la delegación del Estado de Honduras y su renuencia a aceptar que las violaciones a los derechos humanos son estructurales y de naturaleza política, además de la falta de voluntad de combatir la impunidad: 21 naciones emitieron 129 recomendaciones de las que aceptó 5, planteó que 112 están en proceso y 12 las respondería en marzo 2011. Durante el examen se plantearon entre otras las siguientes recomendaciones:

"Adopte las medidas necesarias para la investigación y castigo de las violaciones a los derechos humanos cometidas durante y con posterioridad al golpe de estado". Que adopte medidas efectivas para proteger a las y los periodistas, defensores de derechos humanos y comunicadores sociales, incluidas las radios comunitarias. "Y cuando existan ataques, llevar a cabo investigaciones efectivas para prevenir, investigar y castigar las agresiones que tienen lugar dentro de su jurisdicción". "Que garantice la pluralidad y diversidad particularmente en los medios de comunicación audiovisual". Asimismo, que establezca un marco jurídico e institucional que proteja la libertad de expresión, a través de la despenalización la difamación y otras restricciones a los contenidos; asi como de la adecuada implementación de la ley de acceso a la información."

El Estado de Honduras obvió referirse al golpe de Estado y sus consecuencias en materia de derechos humanos, de igual forma evitó referirse a la falta de investigación en los casos de asesinatos, torturas, secuestros y detenciones ilegales por razones políticas y la existencia de estructuras paralelas a las fuerzas de seguridad del Estado que actúan con su aquiescencia y tolerancia. Pero sí destacó la emisión de una Ley de Amnistía que favorece la impunidad de civiles y militares vinculados al golpe de Estado y la incorporación de militares de alta graduación en las estructuras civiles del aparato Ejecutivo. De igual manera, no informó que se discutía en el Congreso Nacional un anteproyecto de Ley que criminaliza la protesta social y el trabajo de los defensores de derechos humanos-Ley Antiterrorista.

Tampoco informó que fiscalías del Ministerio Público no instruían la investigación y se basaban para acusar a defensores y activistas sociales con la información obtenida de forma ilegal por la policía preventiva, que en la mayoría de los casos había participado de su captura y agresiones a su integridad física ${ }^{50}$.

La conducción del régimen en el Congreso Nacional (integrado con más del 50\% de los mismos diputados que dieron el golpe de estado en 2009) continuó aprobando leyes que afectan los derechos humanos de amplios sectores de la población no organizada, sectores especialmente comunales, sindicales y gremiales.

\section{Educación y Derechos Laborales}

La profunda crisis que sacude al sistema educativo hondureño es otro de los grandes problemas que enfrenta el régimen de Lobo Sosa. Durante el año, las protestas, huelgas generales y jornadas de protestas de los estudiantes y profesores han puesto al desnudo la intervención negativa del golpismo en los asuntos educativos y durante las manifestaciones de reclamo magisterial los

50 Acusaciones en contra de 127 personas durante el 2009, por los Delitos de Sedición, Terrorismo, Incendio Agravado, Asociación ilícita y Manifestaciones ilícitas. 
choques entre educadores, estudiantes y la policía han causado numerosas detenciones, lesionados y heridos. Los alumnos exigen la derogación de una ley de educación introducida en el Congreso Nacional por el dictador Roberto Micheleti y el magisterio el respeto al estatuto del Docente, el aumento al salario mínimo y la devolución de más de 4 mil millones de lempiras a las arcas del Instituto de Previsión del Magisterio.

La profunda crisis que sacude al sistema educativo hondureño se agravó durante el segundo semestre de 2010. Las protestas, huelgas generales y jornadas de protestas de los estudiantes y profesores, han puesto al desnudo los fallos del modelo educativo desigualmente contrastado en el presupuesto de seguridad y defensa. Durante las manifestaciones, los choques entre los estudiantes y la policía han causado numerosas detenciones, heridos y criminalizados.

Uno de los últimos puntos de discrepancia lo constituye el anteproyecto de Ley General de Educación, un instrumento que consta de más de 100 artículos, y que fue elaborado a través del Foro Nacional de Convergencia (FONAC) entre el 2004 y 2009. La propuesta, que sustituye la Ley de Educación de 1966, ya había causado tensión entre el magisterio y el Secretario de Estado en el despacho de Educación del Presidente Zelaya. En el 2009, el proyecto no se introdujo al Congreso porque los colegios magisteriales argumentaron que no había terminado de ser consensuada.

No obstante, en el mes de mayo de 2010 el régimen de Porfirio Lobo retomó el proyecto y lo remitió al Congreso Nacional para su discusión. Las organizaciones magisteriales cuestionan entre otros puntos álgidos de la propuesta de Ley la obligación que tendrían los docentes de alcanzar un nivel académico universitario para poder ingresar al sistema educativo; la creación de un Consejo Nacional de Educación que se encargaría de definir las políticas educativas de Honduras, incluida la educación superior.

Este punto ha venido siendo discutido por diversos sectores ante la incongruencia con la normativa de la Universidad Nacional Autónoma de Honduras (UNAH), institución que por años se ha encargado de definir las políticas de la educación superior en el país.

Al finalizar el 2010, el Congreso Nacional emitió un Decreto Legislativo que por su redacción suspendió el Estatuto del Docente. El 28 de diciembre se público en el diario oficial la Gaceta el Decreto 136-2010. Literalmente el artículo 136 del decreto establece que "a partir de la fecha de vigencia del presente Decreto quedan en suspenso el Decreto Legislativo número 174-2000, de fecha 30 de Octubre de 2000, que contiene la Ley del Estatuto del Docente Hondureño ${ }^{51}$ y el Acuerdo Ejecutivo número 0021-P.E.-2009, de fecha 20 de Noviembre de 2009 y Decreto Legislativo No.151-2009, de fecha 26 de Diciembre del 2009, contentivo de la Ley de Sistema Nacional de Gestión de Riesgos (SINAGER).

El decreto debería contener la desindexación de los estatutos profesionales del aumento al salario mínimo, la Ley aprobada el 27 de octubre de 2010 contemplaba la redacción siguiente: "Adoptar medidas transitorias de emergencia consistentes en que el salario minino que se fije, no deberá ser

$51 \quad$ El Decreto que contiene el Estatuto del Docente es el 136-97 emitido el 11 de septiembre de 1997. 
utilizado como referencia para el incremento de manera automática y directa de los salarios contemplados a servidores públicos regulados por leyes especiales o estatutos profesionales”.

En el artículo 3: "Dejar en suspenso durante la vigencia de este decreto los regímenes económicos establecidos en los diferentes estatutos profesionales". Al cierre de este informe, el Congreso Nacional a través del Presidente de la Comisión Legislativa de Educación Luis Berrios Segovia 52 argumentó que se trató de un error y que se enmendaría con la publicación de fe de erratas ${ }^{53}$ que se remitiría el 24 de enero de 2010. El Decreto Legislativo número 174-2000, contiene la indexación del salario Mínimo al Estatuto del Docente al salario mínimo, el Estatuto del Docente fue aprobado mediante Decreto 136-97 del 11 de septiembre de 1997. Los colegios profesionales se manifestaron públicamente en San Pedro Sula y Tegucigalpa en contra de la redacción del Decreto, manifestaciones que fueron reprimidas, y criminalizados cuatro docentes.

El 07 de junio el Presidente del Congreso Nacional, Juan Orlando Hernández Alvarado, presentó el Programa Para Activar el Trabajo y la Oportunidad (Pacto). El programa contiene seis iniciativas de Ley: Ley Régimen para la Inmigración Legal de Trabajadores, Ley de Empleo por Horas, Ley de Generación de Empleo Rural en Zonas Urbano Marginales, Ley Reguladora del Régimen de Participación Público Privada, la aprobación de los contratos de energía renovable, Ley de Promoción y Protección de Inversión. La aprobación se llevaría a cabo bajo la modalidad de emergencia. El programa fue respaldado por el Consejo Hondureño de la Empresa Privada y la Cámara de Comercio Industrias de Tegucigalpa ${ }^{54}$.

En el marco de esta iniciativa se aprobó el 04 noviembre de 2010 la Ley de Empleo por Horas, el que tendrá una duración de 36 meses prorrogable. Las tres Centrales Obreras ${ }^{55}$ se manifestaron desde el mes de agosto en contra de la Ley porque lesiona los derechos laborales de los trabajadores y los derechos sindicales. La OIT manifestó que esta leyes violentan el convenio 98 y 87 sobre la libertad sindical y la organización colectiva, además violenta la estabilidad laboral el salario mínimo". La OIT presentó en octubre recomendaciones sobre la necesidad de añadir al proyecto de Ley una disposición que señalara claramente que los trabajadores cubiertos por el programa gozaban de los derechos y garantías fundamentales establecidas en la Constitución Nacional y en los Convenios de la OIT ratificados por Honduras. Según los proyectistas del nuevo instrumento los derechos fueron incorporados en su totalidad, pero las centrales obreras difieren sobre el punto y son de la opinión que las opiniones del organismo internacional fueron manipuladas:

52 Diario tiempo página 10 del 22 de enero de 2011.

53 fe de erratas sólo deben referirse a pequeños errores en el texto (por ejemplo, errores de escritura, de ortografía o de puntuación). En cambio si se detecta un error importante en la construcción de una oración, o si la construcción es tal que la idea transmitida por la oración es oscura o distorsionada al punto que la misma es confusa o errónea, este error debe ser corregido dentro del libro o documento y no mediante una fe de errata.

$54 \quad$ Diario la Tribuna del 08 de junio de 2010.

55 Comunicado del 13 de agosto de 2010, San Pedro Sula . 13 de agosto de 2010 CONFEDERACIÓN UNITARIA DE TRABAJADORES DE HONDURAS (CUTH) CONFEDERACIÓN DE TRABAJADORES DE HONDURAS (CTH) CENTRAL GENERAL DE TRABAJADORES (CGT) y comunicado del 03 de noviembre de 2010. 


\section{Concesionamientos de los Recursos Naturales}

En el marco del Programa Para Activar el Trabajo y la Oportunidad, el Congreso de Honduras aprobó la Ley para la Promoción de Energía Eléctrica con Recursos Renovables, una normativa que tiene incidencias ambientales, sociales y económicas en el país, desde el 01 de Junio de 2010. El Congreso aprobó en debates únicos 47 Contratos de Aprovechamiento de Aguas Nacionales para la Generación de Energía Mediante proyectos Hidroeléctricos.

Las organizaciones ambientales y las organizaciones defensoras de los derechos de los pueblos étnicos denunciaron que las comunidades no fueron tomadas en cuenta durante la concesión de los ríos (47 proyectos de concesión) de los cuales el 70\% fueron licitados por empresarios que son los mismos dueños las industrias de energía térmica.

Por otro lado, la Ley no toma en consideración la categorización del Sistema Nacional de Evaluación Ambiental, reglamento que también es seriamente cuestionado por el Instituto de Derecho Ambiental, contra el que se interpuso un recurso de Amparo que no fue admitido por la Corte Suprema de Justicia. Los 47 contratos aprobados ${ }^{56}$ utilizarán el recurso hídrico por treinta años, la Ley señala que los concesionamientos de los ríos pueden ser de 10 a 50 años.

De igual forma se aprobó durante el primer Semestre La Ley de Promoción de Alianzas Públicoprivadas que otorga derechos sobre bienes patrimoniales: áreas protegidas y zonas arqueológicas en modalidades concesiones. En este mismo escenario y teniendo como telón de fondo la declaración de crisis financiera y el Programa Para Activar el Trabajo y la Oportunidad, la Secretaria de Relaciones Exteriores abrió un portal WEB Honduras open for Business", (Honduras está abierta a los negocios), el portal muestra información sobre el marco jurídico nacional para la inversión entre

56 DECRETO No. 46-2010.- Del 01 de Junio de 2010. CONTRATA DE APROVECHAMIENTO DE AGUAS NACIONALES PARA LA GENERACIÓN DE ENERGÍA MEDIANTE EL PROYECTO HIDROELÉCTRICO EL SUEÑO II, suscritos entre la Secretaría de Estado en los Despachos de Recursos Naturales y Ambiente (SERNA) y la Empresa Hidroeléctrica Energía BLUS S.A. DE C.V. la Contrata de Aguas tiene como propósito el aprovechamiento de Aguas Nacionales del cauce natural del Río Palaja, ubicado en el Municipio de El Míspero, Departamento de Santa Bárbara. (SERNA) (ACTA 26) DECRETO No. 47-2010.- Del 01 de Junio de 2010. CONTRATA DE APROVECHAMIENTO DE AGUAS NACIONALES PARA LA GENERACIÓN DE ENERGÍA ELÉCTRICA, MEDIANTE EL PROYECTO CENTRAL HIDROELÉCTRICA “MORJA”, ubicado en el Municipio de El Paraíso, Departamento de Copán, entre la Sociedad Mercantil INGENIERÍA TÉCNICA, S.A. DE C.V. (SERNA) (ACTA 26) DECRETO No. 48-2010.- Del 01 de Junio de 2010. CONTRATO DE OPERACIÓN PARA LA GENERACIÓN DE POTENCIA Y ENERGÍA ELÉCTRICA, PARA LA INSTALACIÓN DE LA CENTRAL HIDROELÉCTRICA “LAS VENTANAS”, ubicado en l Cuenca del Río Uluita del Municipio de Jesús de Otoro, Departamento de Intibucá, suscrito en la ciudad de Tegucigalpa, Municipio del Distrito Central, a los 4 días del mes de Diciembre de 2009, entre la Sociedad PROVEEDORES INTERNACIONAL, S.A. (PROINTER). (SERNA) (ACTA 26). 
estas Ley de Alianza Pública y Privada. Más adelante y antes de que el régimen de Lobo cumpliera sus primer año en el gobierno, el Congreso aprobó la ley de las Regiones Especiales de Desarrollo, popularizada como las "Ciudades Modelo", que serán instaladas en Agalta, Olancho; Trujillo; Ocotepeque y Amapala.

Desarticulación de las Organizaciones Sociales y Ataques a Defensoras y Defensores de Derechos Humanos

Durante el 2010 se Fortalecieron las medidas de desarticulación de las organizaciones sociales. El 18 de noviembre de 2010, el Congreso Nacional aprobó la Ley contra el financiamiento del Terrorismo. Conocida como la Ley Anti Terrorista, que contiene 83 artículos, orientada a incrementar los controles en aduanas terrestres, aéreas y marítimas. De igual forma, obligará a las organizaciones no gubernamentales a reportar ante el Estado cualquier donación o apoyo superior a dos mil dólares ${ }^{57}$, esto incluye concesiones de vehículos o equipos. La ley también Contempla multas de 2000 salarios mínimos, la prohibición de realizar actividades hasta por cinco años o la disolución de la asociación. Las disposiciones contenidas en esta nueva ley no cumplen con los parámetros internacionales en materia procesal.

La impunidad que rodea la muerte de periodistas ha colocado a Honduras en el segundo lugar de países más peligrosos para el ejercicio del periodismo crítico, después de México. Pero también revela signos de la aplicación de los modus operandi de los comandos de operaciones clandestinas, muy similares al modelo Colombiano. Hasta antes del 2010, el asesinato de periodistas no era un patrón de ataque a la libertad de Prensa, expresión e información, desde marzo de 2010, diez periodistas fueron asesinados. La violencia y las amenazas, así como la política de información del actual gobierno y la autocensura, han convertido a Honduras en un país con un déficit informativo y expresivo. El 2010, también incluyó la detención arbitraria de comunicadores sociales y la criminalización de las mismos por el ejercicio de su trabajo.

La impunidad también permitió la intimidación y el espionaje generalizado a otros actores incluyendo defensores de Derechos Humanos. Las acciones ilegales incluyeron interceptaciones de teléfonos y correos electrónicos, seguimientos, hostigamientos y amenazas, robos de información e ingresos ilegales a oficinas y domicilios. Esto provocó un clima de inseguridad y, en algunas ocasiones, de miedo por el sabotaje y descrédito del trabajo de los defensores y las defensoras de derechos humanos. Las acciones contra las mujeres incluyeron amenazas directas contra sus hijos e hijas, en ocasiones con manifiesto contenido sexual violento.

Después de observar las diferentes modalidades de violaciones a los derechos humanos fundamentales podemos señalar que se concentran en repetir el "Modelo Colombiano": Política de Seguridad Democrática, que incluye militarizaciones geográficas, estigmatización de sus oponentes, acusando a organizaciones de derechos humanos nacionales e internacionales de defender el terrorismo; además, fragmentar la sociedad, intimidar a los periodistas, emitir leyes para combatir el terrorismo, incorporación del sistema de administración de justicia a la represión por

57 Capítulo XIII el Funcionamiento y obligaciones de las asociaciones u organizaciones sin fines de lucro. artículo 58.1 
razones políticas, intimidación de los opositores políticos y organizaciones sociales atacando a sus familiares entre otros métodos de represión.

\begin{tabular}{|c|c|c|}
\hline \multicolumn{3}{|c|}{$\begin{array}{l}\text { CUADRO RESUMEN ESTADISTICAS VIOLACIONES A DERECHOS HUMANOS: } 31 \text { DE ENERO } 2010 \text { A } 31 \text { DE ENERO DE } 2011 \\
\text { El Estado hondureño avanza en su dinámica de desarticulación y muerte de los opositores al Golpe de Estado aglutinados en la Resistencia, } \\
\text { los actores armados se consolidan en sus actuaciones de devastación y muerte. La falta de respuesta efectiva de la justicia aumenta ese } \\
\text { círculo de impunidad y el panorama se agrava con el silencio y el terror que se ha impuesto en el país. Las } \\
\text { cifras que se reportan están vinculadas a violaciones a Derechos Humanos por razones políticas en el período Enero } 2010 \text { a Enero de } 2011 . \\
\text { Datos registrados por el COFADEH Comité de Familiares de Detenidos Desaparecidos en Honduras }\end{array}$} \\
\hline DERECHO VIOLADO & Cantida & OBSERVACIONES \\
\hline \multicolumn{3}{|l|}{ DERECHO A LA VIDA } \\
\hline Asesinatos políticos & 34 & \\
\hline Asesinatos por conflicto de tierra & 34 & \\
\hline Homicidios por abuso de autoridad & 28 & \\
\hline Muertes por autoría sospechosa & $309 *$ & 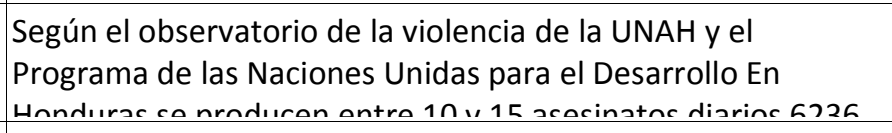 \\
\hline Atentados contra personas y bienes & 23 & \\
\hline Amenazas a Muerte & 274 & 133 amenazados son defensores de derechos humanos \\
\hline Intimidación y persecución & 77 & \\
\hline Agresiones sexuales & 2 & \\
\hline \multicolumn{3}{|l|}{ DERECHO A LA LIBERTAD PERSONAL } \\
\hline Desaparición forzada & 6 & \\
\hline Detenciones ilegales y Detenciones arbitrarias & 431 & \\
\hline Secuestros & 5 & \\
\hline Secuestros en su grado de tentativa & 7 & \\
\hline \multicolumn{3}{|l|}{ DERECHO A LA INTEGRIDAD } \\
\hline Lesiones y Golpes & 96 & \\
\hline Torturas & 26 & \\
\hline \multicolumn{3}{|l|}{ DERECHO A LA INVIOLABILIDAD DEL } \\
\hline Allanamientos & 23 & \\
\hline Barrios y colonias objeto de cateos en horas & 24 & Barrios y colonias perfilados por las fuerzas de seguridad \\
\hline \multicolumn{3}{|l|}{ LIBERTAD DE CIRCULACIÓN Y RESIDENCIA } \\
\hline $\begin{array}{l}\text { Desplazamiento interno por reiteradas } \\
\text { amanaาar }\end{array}$ & 52 & $\begin{array}{l}\text { Personas que han cambiado de ciudad por sentirse } \\
\text { amanazadnc al car minmhrac Noln racictanrin }\end{array}$ \\
\hline Cambio de domicilio por inseguridad & 45 & Personas que han cambiado su domicilio por sufrir amenazas \\
\hline Exiliados por razones políticas & 150 & Personas que no han podido retornar al país \\
\hline Exiliados por razones políticas & 36 & Personas exiliadas durante el período enero 2010 a enero \\
\hline \multicolumn{3}{|l|}{ DERECHO A LA SEGURIDAD PERSONAL } \\
\hline Medidas cautelares $\mathrm{CIDH}^{*}$ & 160 & Personas a las que la CIDH ha otorgado medidas cautelares. \\
\hline Medidas cautelares CIDH* & 19 & Organizaciones a las que la CIDH ha otorgado medidas \\
\hline Solicitud de información CIDH * & 33 & Casos sobre los que la CIDH ha solicitado información al \\
\hline Robo informático & 11 & \\
\hline
\end{tabular}




\begin{tabular}{|l|c|c|}
\hline LIBERTAD DE EXPRESIÓN & & \\
\hline Periodistas asesinados & 10 & \\
\hline Atentados contra periodistas & 1 & \\
\hline Amenazas contra Periodistas y comunicadores & 22 & \\
\hline Detención ilegal de Periodistas y & 4 & \\
\hline Agresiones a Periodistas y comunicadores & 5 & \\
\hline Periodistas exiliados & 6 & \\
\hline Programas cerrados & 1 & \\
\hline Radios comunitarias cerradas & 2 & \\
\hline Atentados contra medios de comunicación & 6 & \\
\hline DERECHO A LA PERSONALIDAD JURIDICA Y & & \\
\hline Represalias & 10 & Cuatro colegios magisteriales y seis sindicatos \\
\hline TOTAL & $\mathbf{1 6 5 8}$ & \\
\hline
\end{tabular}

cuadro elaborado por el CED-COFADEH 